\title{
EVALUASI DANA DESA DAN ALOKASI DANA DESA PADA DESA BANTAN TENGAH TAHUN ANGGARAN 2019
}

\author{
Devita Mardalena1, Suharyono² \\ ${ }^{1}$ Program Study Akuntansi Keuangan Publik, Politeknik Negeri Bengkalis \\ Email:devitamardalenaakp1b@gmail.com \\ ${ }^{2}$ program Study Akuntansi Keuangan Publik, Politeknik Negeri Bengkalis \\ Email: suharyono@polbeng.ac.id
}

\begin{abstract}
ABSTRAK
This research consign to knowing evaluation of village funds and allocation of village funds to the village of Bantan Tengah for the 2019 fiscal year (case study in the village of Central Bantan). The type of research that use in this case as deskriptif kualitatif. The results of this research is showing that the use of village funds and the allocation of village funds in the middle of bantan village have not been used to the fullest, because there are still a number of unrealized. Unrealized funds from village funds are Rp. 113,775,041, -, 9.58\% of the total budget, while funds from the allocation of village funds amounted to Rp. 717,334,285, $32.73 \%$ of the total budget. Activities programs, while the unrealized activities are management of villageowned libraries, construction / rehabilitation / improvement of road infrastructure, social training / extension / about the environment, strengthening and increasing the capacity of security personnel, port maintenance, construction / rehabilitation / upgrading of buildings / infrastructure, developing village information systems, organizing PAUD / TK / TPA / TKA / TPQ / Madrasah, maintenance of residential neighborhood / alley roads, maintenance of facilities cultural infrastructure, youth development / youth / sports clubs, disaster management activities, the most dominant program that is not realized, namely the infrastructure development.
\end{abstract}

Keywords: Village Funds, Village Fund Allocation, Evaluation

\begin{abstract}
ABSTRAK
Penelitian ini bertujuan untuk mengetahui evaluasi dana desa dan alokasi dana desa pada desa Bantan Tengah tahun anggaran 2019 (studi kasus di desa Bantan Tengah). Jenis penelitian yang digunakan adalah kualitatif deskriptif. Hasil penelitian ini menunjukkan bahwa penggunaan dana desa dan alokasi dana desa di desa bantan tengah belum digunakan secara maksimal, karena masih terdapat beberapa program kegiatan yang tidak terealisasi. Total dana yang tidak terealisasi dari dana desa adalah sebesar Rp. 113.775.041,-, 9,58\% dari total anggaran, sedangkan dana dari alokasi dana desa adalah sebesar Rp. 717.334.285,- 32,73\% dari total anggran. Adapun kegiatan yang tidak terealiasi yaitu pengelolaan perpustakaan milik desa, pembangunan/rehabilitasi/peningkatan prasarana jalan, pelatihan sosial/penyuluhan/tentang lingkungan hidup, penguatan dan peningkatan kapasitas tenaga keamanan, pemeliharaan pelabuhan, pembangunan/rehabilitasi/peningkatan gedung/prasarana, pengembangan sistem informasi desa, penyelengagaraan PAUD/TK/TPA/TKA/TPQ/Madrasah, pemeliharaan jalan lingkungan pemukiman/gang, pemeliharaan sarana prasarana kebudayaan, pembinaan karang taruna/klub kepemudaan/olahraga, kegiatan penanggulangan bencana, program paling dominan yang tidak terealisasi yaitu pembangunan infrastruktur.
\end{abstract}

Kata kunci: Dana Desa, Alokasi Dana Desa, Evaluasi 


\section{Pendahuluan}

Desa memiliki tanggungjawab dan kewenangan untuk mengatur dan mengurus yang menyangkut tentang peran pemerintah desa sebagai penyelenggara pelayanan masyarakat di desa dan dalam proses pelaksaan pembangunan. Salah satu hal yang terpenting untuk diperhatikan didalam proses pelaksanaan pembangunan dan pemberdayaan masyarakat disetiap desa adalah kepastian tentang keuangan. Penyaluran dana menjadi hal yang terpenting untuk pembangunan desa agar lebih maju. Didalam Peraturan Pemerintah Nomor 60 Tahun 2014 tentang Dana Desa yang bersumber dari APBN, Pasal 1, ayat 2 Dana Desa adalah Dana yang bersumber dari Anggaran Pendapatan dan Belanja Negara yang diperuntukkan bagi desa yang ditransfer melalui Anggaran Pendapatan dan Belanja Daerah Kabupaten/Kota dan digunakan untuk membiayai penyelenggaraan pemerintahan, pelaksanaan pembangunan, pembinaan kemasyarakatan, dan pemberdayaan masyarakat.

Pembiayaan tersebut juga memiliki hubungan dengan Alokasi Dana Desa sehingga Pemerintah Daerah Kabupaten memberikan bantuan Alokasi Dana Desa kepada setiap Desa yang berada di wilayahnya. Menurut Undang-Undang Nomor 6 Tahun 2014 Tentang Desa, Alokasi Dana Desa paling sedikit 10\% (sepuluh persen) dari dana perimbangan yang diterima Kabupaten/Kota dalam Anggaran Pendapatan dan Belanja Daerah setelah dikurangi Dana Alokasi Khusus. Penggunaan Anggaran Alokasi Dana Desa adalah sebesar 30\% (tiga puluh persen) untuk belanja aparatur dan operasional pemerintahan desa, sebesar 70\% (tujuh puluh persen) untuk biaya pemberdayaan masyarakat.

Desa Bantan Tengah merupakan desa tertua dan sebagai desa induk dari pemekaran desa-desa yang terdapat di Kecamatan Bantan. Desa Bantan Tengah menerima dana desa sebesar Rp 1.187.551.000.- sedangkan alokasi dana desa sebesar Rp 2.191.341.155,- yang akan dipergunakan untuk penyelenggaraan pembangunan, pemberdayaan masyarakat, belanja aparatur dan operasional pemerintahan desa. Atas latar belakang yang tertera, maka penulis tertarik untuk melakukan penelitian yang berjudul Evaluasi Dana Desa dan Alokasi Dana Desa pada Desa Bantan Tengah Tahun Anggaran 2019.

\section{Landasan Teori \\ Penelitian Terdahulu}

Untuk membuktikan orisinalitas dari peneltian yang dilakukan oleh peneliti, maka peneliti menyajikan beberapa penelitian yang sudah ada dan berkaitan dengan yang akan diteliti dalam penelitian ini, antara lain adalah:

1. Olana Christin Pasodung dan Jantje J. Tinangon, (2017) melakukan penelitian dengan judul " Evaluasi penggunaan dana desa tahun 2015 pada badan pemberdayaan masyarakat kampung dan transmigrasi (bpmkt) kabupaten kepulauan yapen,papua Anggaran Pendapatan Dan Belanja Desa (APBDes) Tahun 2017 (Studi Kasus di desa kategori tertinggal pada Kecamatan Kintamani, Kabupaten Bangli)" menemukan hasil bahwa Penyaluran Dana Desa kepada setiap kampung dikabupaten kepulauan yapen pada tahun anggaran 2015 sudah berjalan/ dilaksanakan, namun dalam pengelolaan/penggunaan dan pertanggung jawaban dana desa belum maksimal. 2 . Regulasi yang mengatur tentang penyaluran, pengelolaan/penggunaan, pertanggungjawaban dan pengawasan dana desa yang sering berubah-ubah/ direvisi menyebabkan keragu-raguan bagi pelaksana ditingkat kabupaten khususnya ditingkat pemerintahan kampung. 3. Pengelolaan/penggunaan dana desa ditingkat kampung 
sudah dilaksanakan namun karena sumber daya manusia pengelola sebelumnya tidak dipersiapkan dengan baik, sehingga didalam pelaksanaannya antara rencana kerja/kegiatan dan fakta dilapangan masih ditemui/terdapat ketidak sesuaian.

2. Novita Ayu Handayani, (2019) melakukan penelitian dengan judul " Evaluasi kebijakan alokasi dana desa dalam pembangunan desa di desa jetiskarangpung kecamatan kalijambe kabupaten sragen" hasil dari penelitian ini menunjukkan bahwa kebijakan Alokasi Dana Desa di Desa Jetiskarangpung perlu dilanjutkan karena dapat dipergunakan untuk meningkatkan infrastruktur desa sehinga memberi peluang peningkatan usaha masyarakat dalam rangka menanggulangi kemiskinan serta mendorong gotong royong masyarakat melalui dana-dana stimulan untuk kegiatan pembangunan fisik, kesehatan, dan pendidikan kepemudaan. Hasil penelitian ini konsisten dengan hasil penelitian terdahulu yang dilakukan oleh Maifitriatno (2016) yang menyimpulkan bahwa pelaksanaan Alokasi Dana Desa (ADD) dalam pembangunan di Desa Amang telah dilaksanakan sesuai dengan kebijakan dan peraturan perundangan-undangan

3. Oksep Adhayanto, Bismar Arianto, Winatawira, Suryadi dan Nurhasanah, (2019) Melaukan Penelitian yang berjudul "The Evaluation of the Utilization of the 2018 Village Funds in Bintan District and Lingga District" hasil dari penelitian ini menunjukkan pertama, sebagian besar dana desa digunakan untuk pembangunan fisik desa, sedangkan pengembangan sumber daya manusia tidak dilaksanakan dengan baik karena keterbatasan alokasi dana desa untuk pemberdayaan dan pengembangan masyarakat. Kedua, dampak signifikan yang dirasakan oleh masyarakat adalah pada peningkatan fasilitas fisik dasar di desa, ini berbeda dengan dampak pada pemberdayaan dan ekonomi masyarakat. Ketiga, kendala dalam pelaksanaan dana desa adalah regulasi, sumber daya manusia, dan koordinasi. Rekomendasi dari penelitian ini adalah sebagai berikut, ada kebutuhan untuk penyebaran informasi yang lebih luas dan lebih adil kepada masyarakat, badan konsultatif desa, dan lembaga masyarakat di desa untuk meningkatkan implementasi dan pengelolaan dana desa dan meningkatkan partisipasi masyarakat. Untuk meningkatkan transparansi dan akuntabilitas pemerintah desa dalam pelaksanaan dan pengelolaan dana desa setelah pelaksanaan kegiatan, harus ada cara yang efektif dan sederhana untuk mempublikasikan informasi terkait kepada masyarakat. Selanjutnya, perlu disinergikan antara organisasi perangkat daerah untuk mengoptimalkan implementasi dan pengelolaan dana desa, dan pemerintah daerah perlu menyederhanakan prosedur dan mekanisme pelaksanaan dan pelaporan penggunaan dana desa.

\section{Dana Desa}

Dana desa merupakan dana yang bersumber dari Anggaran Pendapatan dan Belanja Negara yang diperuntukkan bagi Desa yang ditransfer melalui Anggaran Pendapatan dan Belanja Daerah kabupaten/kota, dijelaskan dalam Peraturan Pemerintah Nomor 60 Tahun 2014 pasal 19 ayat 2 dana desa digunakan untuk mendanai penyelenggaraan pemerintahan, pelaksanaan pembangunan, pembinanaan kemasyarakatan, dan pemberdayaan masyarakat. Dana Desa sebagaimana yang dimaksud diprioritaskan untuk pembangunandan pemberdayaan masyarakat desa. Tujuan diberikannya dana desa adalah meningkatkan kesejahteraan masyarakat desa dan kualitas hidup masyarakat desa serta penanggulangan kemiskinan desa melalui peningkatan pelayanan publik di desa, memajukan perekonomian desa, mengatasi 
kesenjangan pembangunan antar desa serta memperkuat masyarakat desa sebagai subyek dari pembangunan. Undang-Undang Desa mengamanatkan anggaran dana desa yang bersumber dari APBN dihitung berdasarkan jumlah desa dan dialokasikan dengan memperhatikan jumlah penduduk, angka kemiskinan, luas wilayah, dan tingkat kesulitan geografis. (Peraturan Pemerintah Nomor 60 Tahun 2014).

\section{Alokasi Dana Desa}

Alokasi dana desa merupakan dana yang dialokasikan oleh pemerintah Kabupaten untuk desa, yang bersumber dari bagian dana perimbangan keuangan pusat dan daerah yang diterima oleh Kabupaten (Peraturan Menteri Dalam Negeri Nomor 113 Tahun 2014). Alokasi dana desa merupakan dana yang cukup signifikan bagi desa untuk menunjang program-program desa. Dalam Peraturan Pemerintah Nomor 72 Tahun 2005 tentang Desa pasal 68 ayat 1 poin c, disebutkan bahwa bagian dari dana perimbangan pusat dan daerah yang diterima oleh kabupaten/kota untuk desa secara proporsional yang merupakan alokasi dana desa. Tujuan dari alokasi dana desa adalah untuk (Permendagri Nomor 37 Tahun 2007):

1. Menanggulangi kemiskinan dan mengurangi kesenjangan.

2. Meningkatkan perencanaan dan penganggaran pembangunan di tingkat desa dan pemberdayaan masyarakat.

3. Meningkatkan pembangunan infrastruktur perdesaan.

4. Meningkatkan pengamalan nilai-nilai keagamaan, sosial budaya dalam rangka mewujudkan peningkatan sosial.

5. Meningkatkan ketentraman dan ketertiban mayarakat

6. Meningkatkan pelayanan pada masyarakat desa dalam rangka pengembangan kegiatan sosial dan ekonomi masyarakat.

7. Mendorong peningkatan keswadayaan dan gotong royong masyarakat.

8. Meningkatkan pendapatan desa dan masyarakat desa melalui Badan Usaha Miliki Desa (BUMDesa).

\section{Metode Penelitian}

\section{Objek Penelitian}

Dalam penelitian ini yang menjadi objek penelitian adalah evaluasi dana desa dan alokasi dana desa pada desa Bantan Tengah tahun anggaran 2019.

\section{Jenis dan Sumber Data}

Jenis data yang digunakan dalam penelitian ini adalah data kualitatif. Sumber data yang digunakan dalam penelitian ini yaitu data primer dan skunder. Data primer yang diperoleh dengan survey lapangan yang menggunakan data original. Dalam penelitian ini sumber data dapat diperoleh dari informasi berupa dokumen dan wawancara secara langsung dengan sekretaris desa, bendahara desa dan masyarakat Desa Bantan Tengah. Data sekunder berupa dokumen-dokumen seperti laporan realisasi anggaran dan laporan pertanggung jawaban kegiatan yang digunakan untuk menganalisis penyusunan anggaran, buku-buku literatur, dan jurnal-jurnal penelitian sebelumnya yang berhubungan dengan penelitian ini

\section{Teknik Pengumpulan Data}

Metode ini digunakan untuk mengetahui seberapa jauh kesesuaian antara teori yang digunakan dengan keadaan yang sebenarnya dari objek yang diteliti. Teknik 
pengumpulan data yang digunakan dalam penelitian ini terdapat tiga teknik yaitu observasi, wawancara dan dokumentasi.

\section{Jenis Penelitian}

Jenis penelitian ini, penelitian kualitatif bersifat deskriptif dengan metode pendekatan studi kasus (case study). Penelitian ini memusatkan diri secara intensif pada satu objek tertentu yang mempelajari sebagai suatu kasus. Data studi kasus dapat diperoleh dari semua pihak yang bersangkutan, dengan kata lain studi ini dikumpulkan dari berbagai sumber. Sugiyono (2017:26) metode kualitatif adalah metode penelitian yang berlandaskan pada filsafat postpositivime digunakan untuk meneliti pada kondisi objek yang alamiah, (sebagai lawannya adalah eksperimen) dilakukan secara triagulasi (gabungan), analisis bersifat induktif, dan hasil penelitian kualitatif lebih menekankan makna daripada generalisasi. Pemilihan jenis penelitian kualitatif dalam penelitian ini dilakukan untuk lebih dapat mengungkap peristiwa dan fakta-fakta yang sesuai dengan judul penelitian yakni evaluasi dana desa dan alokasi dana desa pada desa bantan tengah tahun anggaran 2019.

\section{Metode Analisis Data}

Metode analisis data yang digunakan dalam penelitian kualitatif adalah melalui wawancara dan studi lapangan dalam mendapatkan permasalahan. Teknis analisis data yang dipilih adalah analisis data model Millies dan Huberman, yaitu Pengumpulan data, Reduksi data, Penyajian data dan Conclusion/verification.

\section{Hasil dan Pembahasan}

Bantan Tengah adalah sebuah desa yang terletak sekitar $5 \mathrm{Km}$ dari ibu kota kecamatan Bantan yaitu Selatbaru. Pada zaman dahulu orang lebih mengenal Belas dari pada Bantan Tengah untuk menyebut sebuah daerah disebelah Sungai liong, yang merupakan bagian dari wilayah Desa Selatbaru. Desa bantan tengah menerima dana desa sebesar Rp 1.187.551.000.- sedangkan alokasi dana desa sebesar Rp 2.191.341.155,- yang akan dipergunakan untuk penyelenggaraan pembangunan, pemberdayaan masyarakat, belanja aparatur dan operasional pemerintahan desa.

\section{Realiasai Pelaksanaan Dana Desa Tahun Anggaran 2019}

Indikator yang digunakan peneliti untuk melihat pelaksanaan anggaran alokasi dana desa adalah berdasarkan dari Laporan Realisasi Anggaran Pendapatan dan Belanja Desa Persumber Dana Pemerintah Desa Bantan Tengah Tahun Anggaran 2019.

\subsection{Penggunaan Dana Desa Desa Bantan Tengah Tahun Anggaran 2019} Perbidang Berdasarkan Realisasi Pelaksanaan.

a. Bidang Pelaksanaan Pembangunan Desa

Realisasi penggunaan Alokasi Dana Desa Desa Bantan Tengah tahun anggaran 2019 dapat dilihat pada tabel dibawah ini: 
Tabel 2 realisasi penggunaan DD Desa Bantan Tengah Tahun anggaran 2019 Bidang penyelenggaraan pemerintah desa

\begin{tabular}{|c|c|c|c|}
\hline No & Uraian & & Realisasi \\
\hline & bidang pelaksanaan pembangunan desa & $\mathrm{Rp}$ & $836.429 .700,00$ \\
\hline 1 & sub bidang pendidikan & $\mathrm{Rp}$ & $112.539 .800,00$ \\
\hline 2 & penyelenggaraan PAUD/TK/TPA/TPQ/MADRASAH & $\mathrm{Rp}$ & $43.200 .000,00$ \\
\hline 3 & belanja barang dan jasa & $\mathrm{Rp}$ & $43.200 .000,00$ \\
\hline 4 & belanja jasa honorarium & $\mathrm{Rp}$ & $43.200 .000,00$ \\
\hline 5 & belanja jasa honorarium/insentif/pelayanan desa & $\mathrm{Rp}$ & $43.200 .000,00$ \\
\hline 6 & pembangunan/rehabilitasi/peningkatan/penggadaan sarana & $\mathrm{Rp}$ & $39.171 .600,00$ \\
\hline 7 & belanja modal & $\mathrm{Rp}$ & $39.171 .600,00$ \\
\hline 8 & belanja modal gedung bangunan dan taman & $\mathrm{Rp}$ & $39.171 .600,00$ \\
\hline 9 & $\begin{array}{l}\text { belanja modal gedung bangunan dan taman - honor } \\
\text { pelaksana }\end{array}$ & $\mathrm{Rp}$ & $941.000,00$ \\
\hline 10 & $\begin{array}{l}\text { belanja modal gedung bangunan dan taman - upah tenaga } \\
\text { kerja }\end{array}$ & $\mathrm{Rp}$ & $6.160 .000,00$ \\
\hline 11 & $\begin{array}{l}\text { belanja modal gedung bangunan dan taman - bahan } \\
\text { baku }\end{array}$ & $\mathrm{Rp}$ & $31.506 .600,00$ \\
\hline 12 & $\begin{array}{l}\text { belanja modal gedung bangunan dan taman - biaya } \\
\text { operasional }\end{array}$ & $\mathrm{Rp}$ & $564.000,00$ \\
\hline 13 & pembangunan/rehabilitasi/peningkatan/penggadaan sarana & $\mathrm{Rp}$ & $30.168 .200,00$ \\
\hline 14 & belanja modal & $\mathrm{Rp}$ & $30.168 .200,00$ \\
\hline 15 & belanja modal gedung, bangunan, dan taman & $\mathrm{Rp}$ & $30.168 .200,00$ \\
\hline 16 & $\begin{array}{l}\text { belanja modal gedung, bangunan, dan taman - upah tenaga } \\
\text { kerja }\end{array}$ & $\mathrm{Rp}$ & $7.560 .000,00$ \\
\hline 17 & belanja modal gedung, bangunan, dan taman - bahan baku & $\mathrm{Rp}$ & $22.159 .200,00$ \\
\hline 18 & belanja modal gedung, bangunan, dan taman - biaya operasi & $\mathrm{Rp}$ & $449.000,00$ \\
\hline 19 & pengelolaan perpustakaan milik desa & $\mathrm{Rp}$ & - \\
\hline 20 & belanja modal & $\mathrm{Rp}$ & - \\
\hline 21 & belanja modal lainya & $\mathrm{Rp}$ & - \\
\hline 22 & belanja khusus pendidikan dan perpustakaan & $\mathrm{Rp}$ & - \\
\hline 23 & sub bidang kesehatan & $\mathrm{Rp}$ & $81.900 .000,00$ \\
\hline 24 & penyelenggaraan pos kesehatan desa/polindes milik desa & $\mathrm{Rp}$ & $58.000 .000,00$ \\
\hline 25 & belanja barang dan jasa & $\mathrm{Rp}$ & $58.000 .000,00$ \\
\hline 26 & belanja barang perlengkapan & $\mathrm{Rp}$ & $10.000 .000,00$ \\
\hline 27 & belanja bahan obat-obatan & $\mathrm{Rp}$ & $10.000 .000,00$ \\
\hline 28 & belanja jasa honororium & $\mathrm{Rp}$ & $48.000 .000,00$ \\
\hline 29 & belanja jasa honororium/insentif pelayanan desa & $\mathrm{Rp}$ & $48.000 .000,00$ \\
\hline 30 & penyelenggaraan posyandu & $\mathrm{Rp}$ & $23.900 .000,00$ \\
\hline 31 & belanja barang dan jasa & $\mathrm{Rp}$ & $23.900 .000,00$ \\
\hline 32 & belanja barang perlengkapan & $\mathrm{Rp}$ & $5.000 .000,00$ \\
\hline 33 & belanja barang konsumsi & $\mathrm{Rp}$ & $5.000 .000,00$ \\
\hline 34 & belanja jasa honorarium & $\mathrm{Rp}$ & $18.900 .000,00$ \\
\hline 35 & belanja jasa honorarium/insentif/pelayanan desa & $\mathrm{Rp}$ & $18.900 .000,00$ \\
\hline 36 & sub bidang pekerjaan umum dann penataan ruang & $\mathrm{Rp}$ & $641.989 .900,00$ \\
\hline 37 & pemeliharaan gedung/prasarana balai/balai kemasyarakatan & $\mathrm{Rp}$ & $151.278 .900,00$ \\
\hline
\end{tabular}




\begin{tabular}{|c|c|c|c|}
\hline No & Uraian & & Realisasi \\
\hline 38 & belanja modal & $\mathrm{Rp}$ & $151.278 .900,00$ \\
\hline 39 & belanja modal gedung, bangunan dan taman & $\mathrm{Rp}$ & $151.278 .900,00$ \\
\hline 40 & belanja modal gedunng, bangunan, taman - upah kerja & $\mathrm{Rp}$ & $43.640 .000,00$ \\
\hline 41 & belanja modal gedung, bangunan, taman - bahan baku & $\mathrm{Rp}$ & $105.401 .900,00$ \\
\hline 42 & beklanja modal gedung, bangunan, taman - biaya operasional & $\mathrm{Rp}$ & $2.237 .000,00$ \\
\hline 43 & pembangunan/rehabilitasi/peningkatan/pengerasan jalan & $\mathrm{Rp}$ & $459.658 .100,00$ \\
\hline 44 & belanja modal & $\mathrm{Rp}$ & $459.658 .100,00$ \\
\hline 45 & belanja modal jalan/prasarana jalan & $\mathrm{Rp}$ & $10.831 .000,00$ \\
\hline 46 & belanja modal jalan - honor tim pelaksana kegiatan & $\mathrm{Rp}$ & $42.540 .000,00$ \\
\hline 47 & belanja modal jalan - bahan baku material & $\mathrm{Rp}$ & $390.954 .200,00$ \\
\hline 48 & belanja modal jalan - sewa peralatan & $\mathrm{Rp}$ & $8.250 .000,00$ \\
\hline 49 & belanja modal jalan - biaya operasional kegiatan & $\mathrm{Rp}$ & $7.082 .900,00$ \\
\hline 50 & $\begin{array}{l}\text { pembangunan/rehabilitasi/peningkatan/pengerasan } \\
\text { jembatan }\end{array}$ & $\mathrm{Rp}$ & $31.052 .900,00$ \\
\hline 51 & belanja modal & $\mathrm{Rp}$ & $31.052 .900,00$ \\
\hline 52 & belanja modal jembatan & $\mathrm{Rp}$ & $31.052 .900,00$ \\
\hline 53 & belanja modal jembatan - honor pelaksana kegiatan & $\mathrm{Rp}$ & $747.000,00$ \\
\hline 54 & belanja modal jembatan - upah tenaga kerja & $\mathrm{Rp}$ & $6.400 .000,00$ \\
\hline 55 & belanja moda jembatan - bahan baku/ material & $\mathrm{Rp}$ & $23.457 .900,00$ \\
\hline 56 & belanja modal jembatan - biaya operasional kegiatan & $\mathrm{Rp}$ & $448.000,00$ \\
\hline 57 & pembangunan/rehabilitasi/peningkatan prasarana jalan & $\mathrm{Rp}$ & - \\
\hline 58 & belanja modal & $\mathrm{Rp}$ & - \\
\hline 59 & belanja modal irigasi/embung/drainase/air limbah & $\mathrm{Rp}$ & - \\
\hline 60 & $\begin{array}{l}\text { belaja modal irigasi/embung/drainase/dll }- \text { honor tim } \\
\text { pelaksana }\end{array}$ & $\mathrm{Rp}$ & - \\
\hline 61 & belaja modal irigasi/embung/drainase/dll - upah tenaga kerja & $\mathrm{Rp}$ & - \\
\hline 62 & belaja modal irigasi/embung/drainase/dll - bahan baku & $\mathrm{Rp}$ & - \\
\hline 63 & belaja modal irigasi/embung/drainase/dll - biaya operasional & $\mathrm{Rp}$ & - \\
\hline 64 & sub bidang kehutanan dan lingkungan hidup & $\mathrm{Rp}$ & - \\
\hline 65 & pelatihan/ sosialisasi/ penyuluhan & $\mathrm{Rp}$ & - \\
\hline 66 & belanja barang dan jasa & $\mathrm{Rp}$ & - \\
\hline 67 & belanja barang perlengkapan & $\mathrm{Rp}$ & - \\
\hline 68 & belanja alat tulis kantor dan benda pos & $\mathrm{Rp}$ & - \\
\hline 69 & belanja barang konsumsi & $\mathrm{Rp}$ & - \\
\hline 70 & belanja bendera/umbul-umbul/spanduk & $\mathrm{Rp}$ & - \\
\hline 71 & belanja jasa honorarium & $\mathrm{Rp}$ & - \\
\hline 72 & belanja jasa honorarium tim pelaksana kegiatan & $\mathrm{Rp}$ & - \\
\hline 73 & belanja jasa honorarium tenaga ahli/profesi/konsultan & $\mathrm{Rp}$ & - \\
\hline 74 & belanja perjalanan dinas & $\mathrm{Rp}$ & - \\
\hline 75 & belanaja bantuan trasnportasi & $\mathrm{Rp}$ & - \\
\hline
\end{tabular}

\section{Sumber Data: Laporan Realisasi Anggaran Dana Desa Tahun Anggaran 2019.}

Pemerintah desa memperkirakan anggaran dibidang pelaksanaan pembangunan desa ini adalah sebesar Rp. 1.099.518.900,00 sedangkan yang terealisasi adalah sebesar Rp. 836.429.700,00. Bagian bidang pelaksanaan 
pembangunan desa terdapat beberapa sub bidang, seperti: sub bidang pendidikan, sub bidang kesehatan, sub bidang pekerjaan umum dan penataan ruang, sub bidang kehutanan dan lingkuangan hidup. Setiap bidang sudah dirincikan dana dana yang akan dikeluarkan untuk membuat sebuah kegiatan/pembangunan. Sub bidang pendidikan anggarannya sebesar Rp. 168.793.200,00, anggaran sub bidang kesehatan: Rp. 114.680.000,00 realisasinya: Rp. 81.900.000,00, anggaran sub bidang pekerjaan umum dan penataan ruang: Rp. 811.045.700,00 realisasinya: $641.989 .900,00$, anggaran sub bidang kehutanan dan lingkungan hidup: Rp. 5.000.000,00 realisasinya: 0,00. Anggaran tersebut tidak terealisasi dengan baik, dikarenakan terdapat beberapa kegiatan yang tidak terlaksana,seperti: pengelolaan perpustakaan milik desa, pembangunan/ rehabilitasi/ peningkatan prasarana jalan, pelatihan/ sosialisasi/ penyuluhan tentang lingkungan hidup.

b. Bidang Pembinaan Kemasyarakatan

Realisasi penggunaan Dana Desa Desa Bantan Tengah tahun anggaran 2019 dapat dilihat pada tabel dibawah ini:

Tabel 3 realisasi penggunaan DD Desa Bantan Tengah Tahun anggaran 2019 Bidang Pembinaan Kemasyarakatan

\begin{tabular}{|c|c|c|c|}
\hline No & Uraian & & Realisasi \\
\hline & Bidang Pembinaan Kemasyarakatan & $\mathrm{Rp}$ & $34.162 .000,00$ \\
\hline 1 & sub bidang ketentraman, ketertiban umum dan perlindungan & $\mathrm{Rp}$ & - \\
\hline 2 & penguatan $\%$ peningkatan kapasitas tenaga keamanan & $\mathrm{Rp}$ & - \\
\hline 3 & belanja barang dan jasa & $\mathrm{Rp}$ & - \\
\hline 4 & belanja barang perlengkapan & $\mathrm{Rp}$ & - \\
\hline 5 & belanja barang konsumsi & $\mathrm{Rp}$ & - \\
\hline 6 & belanja bendera/umbul-umbul/spanduk & $\mathrm{Rp}$ & - \\
\hline 7 & belanja barang perlengkapan lainnya & $\mathrm{Rp}$ & - \\
\hline 8 & belanja jasa honorarium & $\mathrm{Rp}$ & - \\
\hline 9 & belanja jasa honorarium tim pelaksana kegiatan & $\mathrm{Rp}$ & - \\
\hline 10 & belanja jasa honorarium tenaga ahli/profesional/konsultan & $\mathrm{Rp}$ & - \\
\hline 11 & belanja perjalanan dinas & $\mathrm{Rp}$ & - \\
\hline 12 & belanja bantuan transportasi & $\mathrm{Rp}$ & - \\
\hline 13 & sub bidang kepudaan dan olahraga & $\mathrm{Rp}$ & $34.162 .000,00$ \\
\hline 14 & pengiriman kontingen kepemudaan \& olahraga & $\mathrm{Rp}$ & $1.880 .000,00$ \\
\hline 15 & belanja barang dan jasa & $\mathrm{Rp}$ & $1.880 .000,00$ \\
\hline 16 & belanja barang perlengkapan lainnya & $\mathrm{Rp}$ & $880.000,00$ \\
\hline 17 & belanja barang konsumsi & $\mathrm{Rp}$ & - \\
\hline 18 & belanja perjalanan dinas & $\mathrm{Rp}$ & - \\
\hline 19 & belanja bantuan transportasi & $\mathrm{Rp}$ & - \\
\hline 20 & belanja barang dan jasa yang diserahkan kepada masyarkat & $\mathrm{Rp}$ & $1.000 .000,00$ \\
\hline 21 & belanja barang untuk diserahkan kepada masyarakat & $\mathrm{Rp}$ & $1.000 .000,00$ \\
\hline 22 & penyelenggaraan festival/lomba kepemudaan dan olahraga & $\mathrm{Rp}$ & $32.282 .000,00$ \\
\hline 23 & belanja barang dan jasa & $\mathrm{Rp}$ & $32.282 .000,00$ \\
\hline 24 & belanja barang perlengkapan & $\mathrm{Rp}$ & $13.470 .000,00$ \\
\hline 25 & belanja alat tulis kantor dan benda pos & $\mathrm{Rp}$ & $220.000,00$ \\
\hline
\end{tabular}




\begin{tabular}{|l|l|lr|}
\hline No & \multicolumn{1}{|c|}{ Uraian } & \multicolumn{2}{c|}{ Realisasi } \\
\hline 26 & belanja barang konsumsi & $\mathrm{Rp}$ & $1.000 .000,00$ \\
\hline 27 & belanja bendera/umbul-umbul/spanduk & $\mathrm{Rp}$ & $1.200 .000,00$ \\
\hline 28 & belanja bahan obat-obatan & $\mathrm{Rp}$ & $3.000 .000,00$ \\
\hline 29 & belanja perlengkapan lainnya & $\mathrm{Rp}$ & $8.050 .000,00$ \\
\hline 30 & belanja jasa honorarium & $\mathrm{Rp}$ & $7.912 .000,00$ \\
\hline 31 & belanja jasa honorarium petugas & $\mathrm{Rp}$ & $432.000,00$ \\
\hline 32 & belanja honorarium laiinya & $\mathrm{Rp}$ & $7.480 .000,00$ \\
\hline 33 & belanja perjalanan dinas & $\mathrm{Rp}$ & $8.200 .000,00$ \\
\hline 34 & belanja bantuan transportasi & $\mathrm{Rp}$ & $8.200 .000,00$ \\
\hline 35 & belanja barang dan jasa yang diserahkan kepada masyarkat & $\mathrm{Rp}$ & $2.700 .000,00$ \\
\hline No & Uraian & \multicolumn{2}{|l|}{ Realisasi } \\
\hline 36 & belanja bahan perlengkapan untuk diserahkan kepada masyarakat & $\mathrm{Rp}$ \\
\hline
\end{tabular}

Sumber Data: Laporan Realisasi Anggaran Lokasi Dana Desa Tahun Anggaran 2019.

Pemerintah desa memperkirakan anggaran dibidang pembinaan kemasyarakatan ini adalah sebesar Rp. 45.001.100,00 sedangkan yang terealisasi adalah sebesar Rp. 34.162.000,00. Bagian bidang pelaksanaan pembangunan desa terdapat beberapa sub bidang, seperti: sub bidang ketentraman, ketertiban umum dan perlingungan, sub bidang kepemudaan dan olahraga. Setiap bidang sudah dirincikan dana dana yang akan dikeluarkan untuk membuat sebuah kegiatan/pembangunan. Sub bidang ketentraman, ketertiban umum dan perlingungan anggarannya sebesar Rp. 5.000.000,00 realisasinya; Rp. 0,00, anggaran sub bidang kepemudaan dan olahraga: Rp. 40.001.100,00 realisasinya: Rp. 34.162.000,00. Anggaran tersebut belum terealiasikan dengan baik, hal itu dikarenakan terdapat kegiatan yang belum terlaksana, kegiatan tersebut adalah penguatan dan peningkatan kapasitas tenaga keamanan

c. Bidang Pemberdayaan Masyarakat

Realisasi penggunaan Dana Desa Desa Bantan Tengah tahun anggaran 2019 dapat dilihat pada tabel dibawah ini:

Tabel 4 realisasi penggunaan DD Desa Bantan Tengah Tahun anggaran 2019 Bidang Pembinaan Kemasyarakatan

\begin{tabular}{|l|l|ll|}
\hline No & \multicolumn{1}{|c|}{ Uraian } & \multicolumn{2}{c|}{ Realisasi } \\
\hline 1 & Bidang Pemberdayaan Masyarakat & $\mathrm{Rp}$ & - \\
\hline 2 & sub bidang kelautan dan perikanan & $\mathrm{Rp}$ & - \\
\hline 3 & pemeliharaan pelabuhan dan perikan & $\mathrm{Rp}$ \\
\hline 4 & pemeliharaan pelabuhan perikanan sungai & $\mathrm{Rp}$ & - \\
\hline 5 & belanja modal & $\mathrm{Rp}$ \\
\hline 6 & belanja modal jembatan & $\mathrm{Rp}$ & - \\
\hline 7 & belanja modal jembatan - honor pelaksanaan kegiatan & $\mathrm{Rp}$ & - \\
\hline 8 & belanja modal jembatan - upah kerja kerja & $\mathrm{Rp}$ & - \\
\hline 9 & belanja modal jembatan - bahan baku/material & $\mathrm{Rp}$ & - \\
\hline 10 & belanja modal jembatan - biaya operasional kegiatan & $\mathrm{Rp}$ & - \\
\hline
\end{tabular}

Sumber Data: Laporan Realisasi Anggaran Dana Desa Tahun Anggaran 2019. 
Pemerintah desa memperkirakan anggaran dibidang pemberdayaan masyarakat ini adalah sebesar Rp. 43.031.000,00 sedangkan yang terealisasi adalah sebesar Rp. 0,00 hal ini dikarenakan dibidang pemberdayaan masyarakat ini memiliki kegiatan yang tidak terlaksanakan yaitu: pemeliharaan pelabuhan perikanan sungai kecil.

Dapat dilihat dari tabel-tabel diatas yang membahas tentang realisasi penggunaan Dana Desa Bantan Tengah Tahun anggaran 2019 belum terlaksana dengan baik, karena masih terdapat beberapa program kegiatan yang belum terlaksana/terealisasi yaitu: pengelolaan perpustakaan milik desa, pembangunan/rehabilitasi/peningkatan prasarana jalan, pelatihan/sosialisasi/penyadaran tentang LHP, penguatan dan peningkatan kapasitas tenaga keamanan, pemeliharaan pelabuhan perikanan sungai milik desa. Hasil dari evaluasi memperlihatkan bahwa penggunaan dana desa tahun anggaran 2019 di desa bantan tengah lebih banyak digunakan untuk pembangunan infrastrutur desa dan untuk penyelenggaraan festival/ lomba kepemudaan dan olahraga.

\subsection{Penerapan/pelaksanaan Pengelolaan Dana Desa Menurut Permendagri}

No. 114 Tahun 2014 dan No. 20 Tahun 2018.

Penerpan dan pelaksanaan merupakan tindakan-tindakan yang dilaksnakan oleh invidu dan kelompok pemerintah maupun swasta. Yang diarahkan pada pencapaian suatu tujuan dan tepat sasaran.

Berikut merupakan tabel perbandingan penerapan/pelaksanaan dana desa tahun anggaran 2019 desa bantan tengah dengan pemendagri No 114 Tahun 2014 dan 20 Tahun 2018:

Tabel 5 Penerapan/pelaksanaan pengelolaan dana desa tahun 2019 Menurut Permendagri No. 114 Tahun $2014 \& 20$ Tahun 2018

\begin{tabular}{|c|c|c|}
\hline No & $\begin{array}{l}\text { Permendagri No. 114 Tahun } 2014 \& 20 \text { Tahun } \\
2018\end{array}$ & $\begin{array}{c}\text { Pelaksanaan dan Penerapan } \\
\text { pengelolaan Dana Desa Tahun } \\
\text { Anggaran } 2019\end{array}$ \\
\hline \multicolumn{3}{|c|}{ Bidang Pembangunan Desa } \\
\hline 1. & $\begin{array}{l}\text { Pembangunan, pemanfaatan, pemeliharaan, } \\
\text { infrastruktur dan lingkungan desa } \\
\text { seperti:Tambatan perahu, jalan permukiman, jalan } \\
\text { desa antar permukiman ke wilayah pertanian, } \\
\text { pembangkit listrik dan mikrohidra, lingkungan } \\
\text { permukiman masyarakat desa }\end{array}$ & - \\
\hline 2. & $\begin{array}{l}\text { Pembangunan,pemanfaatan dan pemeliharaan } \\
\text { sarana dan prasarana kesehatan antara lain: air } \\
\text { bersih berskala desa, sanitasi lingkungan, } \\
\text { pelayanan kesehatan, sarana dan prasarana } \\
\text { kesehatan lainnya. }\end{array}$ & $\begin{array}{l}\text { Penyelenggaraan Pos } \\
\text { Desa/Polindes mikik desa }\end{array}$ \\
\hline 3. & $\begin{array}{l}\text { Pembangunan, pemanfaatan, pemeliharaan } \\
\text { sarana dan prasarana pendidikan dan } \\
\text { kebudayaan antara lain: Taman bacaan } \\
\text { masyarakat, PAUD, balai pelatihan/kegiatan } \\
\text { belajar masyarakat, pengembangan dan } \\
\text { pembinaan sanggar seni, sarana dan prasarana } \\
\text { pendidikan dan pelatihan lainnya sesuai kondoisi } \\
\text { desa }\end{array}$ & $\begin{array}{l}\text { Penyelenggaraan } \\
\text { PAUD/TK/TPA/TPQ/Madrasah }\end{array}$ \\
\hline 4. & $\begin{array}{l}\text { Pengembangan usaha ekonomi produktif serta } \\
\text { pembangunan, pemanfaatan, pemeliharaan }\end{array}$ & $\begin{array}{l}\text { Pemeliharaan } \\
\text { Gedung/Prasarana Balai Desa }\end{array}$ \\
\hline
\end{tabular}




\begin{tabular}{|c|c|c|}
\hline No & $\begin{array}{l}\text { Permendagri No. } 114 \text { Tahun } 2014 \& 20 \text { Tahun } \\
2018\end{array}$ & $\begin{array}{c}\text { Pelaksanaan dan Penerapan } \\
\text { pengelolaan Dana Desa Tahun } \\
\text { Anggaran } 2019\end{array}$ \\
\hline & $\begin{array}{l}\text { sarana dan prasarana ekonomi antara lain: pasar } \\
\text { desa, pembentukan dan pembangunan pasar } \\
\text { desa,penguatan permodalan bumdesa, sarana } \\
\text { dan prasarana sesuai kondisi desa dan lain-lain. }\end{array}$ & $\begin{array}{llr}2 . & \text { Pembangunan/ } & \text { Rehabilitasi/ } \\
\text { Peningkatan jalan } & \text { (tidak } \\
\text { terealisasi) } & & \end{array}$ \\
\hline 5. & $\begin{array}{l}\text { Pelestarian lingkungan hidup antara lain: } \\
\text { penghijauan, pembuatan terasering, } \\
\text { pemeliharaan hutan bakau, perlindungan mata air, } \\
\text { pemebersihan daerah aliran sungai, perlindungan } \\
\text { terumbu karang, dan kegiatan desa lainnya }\end{array}$ & - \\
\hline \multicolumn{3}{|c|}{ Bidang Pembinaan Masyarakat } \\
\hline 1. & Pembinaan lembaga kemasyarakatan. & - \\
\hline 2. & Penyelenggaraan ketentraman dan ketertiban. & $\begin{array}{l}\text { Penguatan dan peningkatan, ketertiban } \\
\text { umum dan perlindungan }\end{array}$ \\
\hline 3. & Pembinaan kerukunan umat beragama. & - \\
\hline 4. & Pengadaan sarana dan prasarana olahraga. & - \\
\hline 5. & Pembinaan lembaga adat & - \\
\hline 6. & $\begin{array}{l}\text { Pembinaan kesenian dan sosial budaya } \\
\text { masyarakat. }\end{array}$ & $\begin{array}{ll}\text { 1. } & \text { Pengiriman } \\
\text { kepemudaan dan olahraga } \\
\text { 2. } \\
\text { Penyelenggaraan festival//omba } \\
\text { kepemudaan dan Olahraga }\end{array}$ \\
\hline 7. & Kegiatan lain sesuai kondisi desa. & ( \\
\hline \multicolumn{3}{|c|}{ Pemberdayaan Masyarakat } \\
\hline 1. & \begin{tabular}{|l}
$\begin{array}{l}\text { Pelatihan usaha ekonomi, pertanian dan } \\
\text { perdagangan }\end{array}$ \\
\end{tabular} & - \\
\hline 2. & Pelatihan teknologi tepat guna & - \\
\hline 3. & $\begin{array}{l}\text { Pendidikan, pelatihan, penyuluhan bagi kepala } \\
\text { desa, perangkat desa dan BPD. }\end{array}$ & - \\
\hline 4. & Peningkatan kapasitas masyarakat. & - \\
\hline
\end{tabular}

\section{Sumber Data: Data Olahan 2020}

Berdasarkan tabel 5.4 dapat dilihat perbandingan antara ketentuan permendagri No 114 tahun 2014 dan No 20 tahun 2018 pada penerapan/pelaksanaan pengelolaan penggunaan dana desa tahun anggaran 2019 desa bantan tengah. Sesuai dengan hasil penelitan, penerapan/pelaksanaan pengelolaan penggunaan dana desa belum sesuai dengan pemendagri No 114 tahun 2014 pasal 17 tentang klasifikasi belanja desa dan No 20 tahun 2018 pasal 6 tentang penyusunan RPJM Desa yang memuat visi dan misi kepala desa, karena masih banyak rancangan arah kebijakan yang belum terlaksana, seperti:

1. Pembangunan, pemanfaatan, pemeliharaan, infrastruktur dan lingkungan desa seperti:Tambatan perahu, jalan permukiman, jalan desa antar permukiman ke wilayah pertanian, pembangkit listrik dan mikrohidra, lingkungan permukiman masyarakat desa

2. Pelestarian lingkungan hidup antara lain: penghijauan, pembuatan terasering, pemeliharaan hutan bakau, perlindungan mata air, pemebersihan daerah aliran sungai, perlindungan terumbu karang, dan kegiatan desa lainnya

3. Pembinaan lembaga kemasyarakatan.

4. Pembinaan kerukunan umat beragama.

5. Penggadaan sarana dan prasarana olahraga

6. Pembinaan lembaga adat

7. Kegiatan lain sesuai kondisi desa. 
8. Pelatihan usaha ekonomi, pertanian dan perdaganganPelatihan teknologi tepat guna

9. Pendidikan, pelatihan, penyuluhan bagi kepala desa, perangkat desa dan BPD.

10. Peningkatan kapasitas masyarakat

2. Realiasai Pelaksanaan Dana Alokasi Dana Desa Tahun Anggaran 2019

Indikator yang digunakan peneliti untuk melihat pelaksanaan anggaran alokasi dana desa adalah berdasarkan dari Laporan Realisasi Anggaran Pendapatan dan Belanja Desa Persumber Dana Pemerintah Desa Bantan Tengah Tahun Anggaran 2019.

2.1. Penggunaan ADD Desa Bantan Tengah Tahun Anggaran 2019 Perbidang Berdasarkan Realisasi Pelaksanaan.

a. Bidang Penyelenggaraan Pemerintahan Desa

Realisasi penggunaan Alokasi Dana Desa Desa Bantan Tengah tahun anggaran 2019 dapat dilihat pada tabel dibawah ini:

Tabel 6 realisasi penggunaan ADD Desa Bantan Tengah Tahun anggaran 2019 Bidang penyelenggaraan pemerintah desa

\begin{tabular}{|c|c|c|}
\hline No & Uraian & Realisasi \\
\hline & Bidang Penyelengaraan Pemerintahan Desa & Rp 1.000.987.500,00 \\
\hline 1 & Penyelenggaraan Belanja Siltap, Tunjangan dan Operasional & $873.937 .500,00$ \\
\hline 2 & penyediaan Penghasilan Tetap dan Tunjangan Kepala Desa & $40.500 .000,00$ \\
\hline 3 & Belanja Pegawai & $40.500 .000,00$ \\
\hline 4 & penghasilan tetap dan tunjangan kepala desa & $40.500 .000,00$ \\
\hline 5 & penghasilan tetap kepala desa & $31.500 .000,00$ \\
\hline 6 & tunjangan kepala desa & $9.000 .000,00$ \\
\hline 7 & penyediaan penghasilan tetap dan tunjangan perangkat desa & $202.200 .000,00$ \\
\hline 8 & belanja pegawai & $202.200 .000,00$ \\
\hline 9 & penghasilan tetap dan tunjangan perangkat desa & $202.200 .000,00$ \\
\hline 10 & penghasilan tetap perangkat desa & $157.500 .000,00$ \\
\hline 11 & tunjangan perangkat desa & $44.700 .000,00$ \\
\hline 12 & penyediaan operasional pemerintah des (ATK, Honor) & $120.935 .000,00$ \\
\hline 13 & Belanja Pegawai & $31.500 .000,00$ \\
\hline 14 & honorarium pengelolaan keuangan desa & $31.500 .000,00$ \\
\hline 15 & honorarium PKPKD & $13.500 .000,00$ \\
\hline 16 & Honorarium PPKD & $18.000 .000,00$ \\
\hline 17 & honorarium pembantu kaur keuangan/bendahara & $\mathrm{Rp}$ \\
\hline 18 & belanja barang dan jasa & $89.435 .000,00$ \\
\hline 19 & belanja barang perlengkapan & $66.935 .000,00$ \\
\hline 20 & belanja alat tulis kantor dan benda pos & $20.000 .000,00$ \\
\hline 21 & belanja perlengkapan alat-alat listrik & $3.175 .000,00$ \\
\hline 22 & belanja perlengkapan alat rumah tangga & $1.500 .000,00$ \\
\hline 23 & belanja bahan bakar minyak/gas/isi ulang tabung & $5.000 .000,00$ \\
\hline 24 & belanja barang cetak dan penggadaan & $10.000 .000,00$ \\
\hline 25 & belanja barang konsumsi & $17.500 .000,00$ \\
\hline 26 & belanja bahan material & $5.000 .000,00$ \\
\hline 27 & belanja bendera/umbul-umbul/spanduk & $\mathrm{Rp}$ \\
\hline
\end{tabular}


ISSN 2657-1080

ISSN 1858-3687

Akuntansi dan Manajemen Vol.15, No.2, 2020

\begin{tabular}{|c|c|c|c|}
\hline No & Uraian & & Realisasi \\
\hline 28 & belanja pakian dinas/seragam/atribut & Rp & $4.760 .000,00$ \\
\hline 29 & belanja perjalanan dinas & $\mathrm{Rp}$ & - \\
\hline 30 & belanja perjalanan dinas dalam kabupaten/kota & $\mathrm{Rp}$ & - \\
\hline 31 & belanja operasional perkantoran & $\mathrm{Rp}$ & $22.500 .000,00$ \\
\hline 32 & belanja jasa langganan listrik & $\mathrm{Rp}$ & $11.700 .000,00$ \\
\hline 33 & bekanja jasa langganan majalah/surat kabar & $\mathrm{Rp}$ & $3.600 .000,00$ \\
\hline 34 & belanja jasa langganan internet & $\mathrm{Rp}$ & $7.200 .000,00$ \\
\hline 35 & belanja jasa perpajakan/izin pajak & $\mathrm{Rp}$ & - \\
\hline 36 & penyediaan tunjangan BPD & $\mathrm{Rp}$ & $171.000 .000,00$ \\
\hline 37 & Belanja Pegawai & $\mathrm{Rp}$ & $171.000 .000,00$ \\
\hline 38 & tunjangan dan jaminan kesehatan BPD & $\mathrm{Rp}$ & $171.000 .000,00$ \\
\hline 39 & tunjangan kedudukan BPD & $\mathrm{Rp}$ & $171.000 .000,00$ \\
\hline 40 & penyediaan operasional BPD (Rapat, ATK, makan, minum) & $\mathrm{Rp}$ & $8.852 .500,00$ \\
\hline 41 & belanja barang dan jasa & $\mathrm{Rp}$ & $8.852 .500,00$ \\
\hline 42 & belanja barang perlengkapan & $\mathrm{Rp}$ & $8.852 .500,00$ \\
\hline 43 & belanja alat tulis kantor dan benda pos & $\mathrm{Rp}$ & $2.146 .500,00$ \\
\hline 44 & belanja barang cetak dan penggadaan & $\mathrm{Rp}$ & $5.500 .000,00$ \\
\hline 45 & belanja barang konsumsi & $\mathrm{Rp}$ & $1.206 .000,00$ \\
\hline 46 & belanja bendera/umbul-umbul/spanduk & $\mathrm{Rp}$ & - \\
\hline 47 & belanja pakian dinas/seragam/atribut & $\mathrm{Rp}$ & - \\
\hline 48 & belanja perjalanan dinas & $\mathrm{Rp}$ & - \\
\hline 49 & belanja perjalanan dinas kabupaten/kota & $\mathrm{Rp}$ & - \\
\hline 50 & penyediaan insentif operasional RT/RW & $\mathrm{Rp}$ & $126.900 .000,00$ \\
\hline 51 & belanja barang dan jasa & $\mathrm{Rp}$ & $126.900 .000,00$ \\
\hline 52 & belanja barang perlengkapan & $\mathrm{Rp}$ & $43.628 .000,00$ \\
\hline 53 & belanja alat tulis kantor dan benda pos & $\mathrm{Rp}$ & $29.072 .000,00$ \\
\hline 54 & belanja barang cetak dan penggadaan & $\mathrm{Rp}$ & $14.556 .000,00$ \\
\hline 55 & belanja perjalanan dinas & $\mathrm{Rp}$ & $83.272 .000,00$ \\
\hline 56 & belanja bantuan transportasi & $\mathrm{Rp}$ & $83.272 .000,00$ \\
\hline 57 & honorarium beban kerja kepala desa dan perangkat desa & $\mathrm{Rp}$ & $53.250 .000,00$ \\
\hline 58 & belanja pegawai & $\mathrm{Rp}$ & $53.250 .000,00$ \\
\hline 59 & honorarium beban kerja kepala desa dan perangkat desa & $\mathrm{Rp}$ & $53.250 .000,00$ \\
\hline 60 & honorarium kepala desa & $\mathrm{Rp}$ & $9.000 .000,00$ \\
\hline 61 & honorarium perangkat desa & $\mathrm{Rp}$ & $44.250 .000,00$ \\
\hline 62 & honorarium staff desa & $\mathrm{Rp}$ & $150.300 .000,00$ \\
\hline 63 & belanja pegawai & $\mathrm{Rp}$ & $150.300 .000,00$ \\
\hline 64 & honoraorium dan jaminan sosial staff desa & $\mathrm{Rp}$ & $150.300 .000,00$ \\
\hline 65 & honorarium staff desa & $\mathrm{Rp}$ & $150.300 .000,00$ \\
\hline 66 & penyediaan sarana prasarana pemerintahan desa & Rp & $67.200 .000,00$ \\
\hline 67 & penyediaan sarana (aset tetap) perkantoran/pemerintahan & $\mathrm{Rp}$ & $56.300 .000,00$ \\
\hline 68 & belanja modal & $\mathrm{Rp}$ & $56.300 .000,00$ \\
\hline 69 & belanja modal penggadaan peralatan, mesin dan alat berat & $\mathrm{Rp}$ & $56.300 .000,00$ \\
\hline 70 & belanja modal peralatan elektronik dan alat studio & $\mathrm{Rp}$ & $20.000 .000,00$ \\
\hline
\end{tabular}




\begin{tabular}{|c|c|c|c|}
\hline No & Uraian & & Realisasi \\
\hline 71 & belanja modal peralatan komputer & Rp & $8.500 .000,00$ \\
\hline 72 & belanja modal peralatan mebelair dan aksesoris ruangan & $\mathrm{Rp}$ & $27.800 .000,00$ \\
\hline 73 & belanja modal kendaraan & $\mathrm{Rp}$ & - \\
\hline 74 & belanja modal kendaraan darat bermotor & Rp & - \\
\hline 75 & pemeliharaan gedung/prasarana kantor desa & $\mathrm{Rp}$ & $10.900 .000,00$ \\
\hline 76 & belanja barang dan jasa & $\mathrm{Rp}$ & $10.900 .000,00$ \\
\hline 77 & belanja pemeliharaan & Rp & $10.900 .000,00$ \\
\hline 78 & belanja pemeliharaan kendaraan bermotor & $\mathrm{Rp}$ & $5.000 .000,00$ \\
\hline 79 & belanja pemeliharaan peralatan & $\mathrm{Rp}$ & $5.900 .000,00$ \\
\hline 80 & belanja pemeliharaan bangunan & Rp & - \\
\hline 81 & pembangunan/rehabilitas/peningkatan/gedung/prasarana & $\mathrm{Rp}$ & - \\
\hline 82 & belanja modal & $\mathrm{Rp}$ & - \\
\hline 83 & belanja modal gedung, bangunan, dan taman - honor & Rp & - \\
\hline 84 & belanja modal gedung, bangunan, dan taman - upah tenaga kerja & $\mathrm{Rp}$ & - \\
\hline 85 & belanja modal gedung, bangunan, dan taman - bahan baku & $\mathrm{Rp}$ & - \\
\hline 86 & belanja modal gedung, bangunan, dan taman - biaya operasional & $\mathrm{Rp}$ & - \\
\hline 87 & pengelolaan administrasi kependudukan & $\mathrm{Rp}$ & - \\
\hline 88 & penyusunan, pendapatan, dan pemutakhiran profil desa & $\mathrm{Rp}$ & - \\
\hline 89 & belanja barang dan jasa & Rp & - \\
\hline 90 & belanja barang perlengkapan & $\mathrm{Rp}$ & - \\
\hline 91 & belanja alat tulis kantor dan benda pos & $\mathrm{Rp}$ & - \\
\hline 92 & belanja barang cetak dan penggadaan & Rp & - \\
\hline 93 & belanja barang konsumsi & $\mathrm{Rp}$ & - \\
\hline 94 & penyelenggaraam tata praja pemerintahan & $\mathrm{Rp}$ & $59.850 .000,00$ \\
\hline 95 & penyelenggaraan musyawarah perencanaan desa & $\mathrm{Rp}$ & $10.000 .000,00$ \\
\hline 96 & belanja barang dan jasa & $\mathrm{Rp}$ & $10.000 .000,00$ \\
\hline 97 & belanja barang perlengkapan & $\mathrm{Rp}$ & $10.000 .000,00$ \\
\hline 98 & belanja barang konsumsi & $\mathrm{Rp}$ & $10.000 .000,00$ \\
\hline 99 & penyusunan dokumen perencanaan desa & Rp & $20.000 .000,00$ \\
\hline 100 & belanja barang dan jasa & Rp & $20.000 .000,00$ \\
\hline 101 & belanja barang perlengkapan & $\mathrm{Rp}$ & $7.385 .000,00$ \\
\hline 102 & belanja alat tulis kantor dan benda pos & Rp & $1.050 .000,00$ \\
\hline 103 & belanja barang cetak dan penggadaan & Rp & $3.489 .000,00$ \\
\hline 104 & belanja barang konsumsi & $\mathrm{Rp}$ & $2.846 .000,00$ \\
\hline 105 & belanja jasa honorarium & Rp & $12.615 .000,00$ \\
\hline 106 & belanja jasa honorarium tim pelaksanaan kegiatan & Rp & $12.615 .000,00$ \\
\hline 107 & penyusunan dokumen keuangan desa & $\mathrm{Rp}$ & $10.000 .000,00$ \\
\hline 108 & belanja barang dan jasa & Rp & $10.000 .000,00$ \\
\hline 109 & belanja barang perlengkapan & Rp & $10.000 .000,00$ \\
\hline 110 & belanja alat tulis kantor dan benda pos & Rp & $3.160 .000,00$ \\
\hline 111 & belanja barang cetak dan penggadaan & Rp & $3.628 .000,00$ \\
\hline 112 & belanja barang konsumsi & $\mathrm{Rp}$ & $3.212 .000,00$ \\
\hline 113 & penyusunan kebijakan desa & $\mathrm{Rp}$ & $14.850 .000,00$ \\
\hline
\end{tabular}




\begin{tabular}{|l|l|lr|}
\hline No & \multicolumn{1}{|c|}{ Uraian } & \multicolumn{2}{c|}{ Realisasi } \\
\hline 114 & belanja pegawai & $\mathrm{Rp} 14.850 .000,00$ \\
\hline 115 & tunjangan dan jaminan kesehatan BPD & $\mathrm{Rp} \quad 14.850 .000,00$ \\
\hline 116 & tunjangan kinerja BPD & $\mathrm{Rp} \quad 14.850 .000,00$ \\
\hline 117 & pengembangan sistem informasi dessa & $\mathrm{Rp}$ & - \\
\hline 118 & belanja barang dan jasa & $\mathrm{Rp}$ & - \\
\hline 119 & belanja jasa honoraroim & $\mathrm{Rp}$ & - \\
\hline 120 & belanja jasa honoraroium tenaga ahli konsultan & $\mathrm{Rp}$ & - \\
\hline 121 & belanja modal & $\mathrm{Rp}$ & - \\
\hline 122 & belanja modal penggadaan peralatan, mesin dan alat berat & $\mathrm{Rp}$ & \\
\hline 123 & belanja modal pembayaran honor tim pelaksanaan kegiatan & $\mathrm{Rp}$ & \\
\hline 124 & dukungan dan sosialisasi pelaksanaan pilkades & $\mathrm{Rp}$ & $5.000 .000,00$ \\
\hline 125 & belanja barang dan jasa & $\mathrm{Rp}$ & $5.000 .000,00$ \\
\hline 126 & belanja barang perlengkapan & $\mathrm{Rp}$ & $1.397 .500,00$ \\
\hline 127 & belanja alat tulis kantor dan benda pos & $\mathrm{Rp}$ & $65.000,00$ \\
\hline 128 & belanja barang cetak dan penggadaan & $\mathrm{Rp}$ & $70.000,00$ \\
\hline 129 & belanja barang konsumsi & $\mathrm{Rp}$ & $1.112 .500,00$ \\
\hline 130 & belanja bendera/umbul-umbul/spanduk & $\mathrm{Rp}$ & $150.000,00$ \\
\hline 131 & belanja jasa honorarium & $\mathrm{Rp}$ & $3.602 .500,00$ \\
\hline 132 & belanja jasa honorarium tim pelaksanaan kegiatan & $\mathrm{Rp}$ & $3.602 .500,00$ \\
\hline
\end{tabular}

Sumber Data: Laporan Realisasi Anggaran Alokasi Dana Desa Tahun Anggaran 2019.

Pemerintah desa memperkirakan anggaran dibidang penyelenggaraan pemerintahan desa ini adalah sebesar Rp. 1.648.152.551,00 sedangkan yang terealisasi adalah sebesar Rp. 1.000.987.500,00. Bagian bidang penyelenggaraan pemerintahan desa terdapat kegiatan seperti: penyelenggaraan belanja siltap, pembangunan/ rehabilitasi/ peningkatan gedung, tunjangan dan operasional perangkat desa, penyediaan sarana prasarana pemerintah desa, dan pengelolaan administrasi kependudukan, pencatatan sipil. Salah satu dari kegiatan tersebut ada yang tidak terlaksanakan yaitu: pembangunan/ rehabilitasi/ peningkatan gedung dan pengelolaan administrasi kependudukan, pencatatan sipil.

b. Bidang Pelaksanaan Pembangunan Desa

Realisasi penggunaan Alokasi Dana Desa Desa Bantan Tengah tahun anggaran 2019 pada bidang pelaksanaan pembangunan desa dapat dilihat pada tabel dibawah ini:

Tabel 7 realisasi penggunaan ADD Desa Bantan Tengah Tahun anggaran 2019 Bidang pelaksanaan pembangunan desa

\begin{tabular}{|l|l|lc|}
\hline No & \multicolumn{1}{|c|}{ Uraian } & \multicolumn{2}{c|}{ Realisasi } \\
\hline & Bidang Pelaksanaan Pembangunan Desa & $\mathrm{Rp}$ & $18.182 .500,00$ \\
\hline 1 & sub bidang pendidikan & $\mathrm{Rp}$ & - \\
\hline 2 & penyelenggaraan PAUD/TK/TPA/TPQ/MADRASAH & $\mathrm{Rp}$ & - \\
\hline 3 & belanja barang dan jasa & $\mathrm{Rp}$ & - \\
\hline 4 & belanja barang dan jasa yang diserahka kepada masyarakat & $\mathrm{Rp}$ & - \\
\hline
\end{tabular}




\begin{tabular}{|c|c|c|c|}
\hline No & Uraian & & Realisasi \\
\hline 5 & $\begin{array}{l}\text { belanja bahan perlengkapan untuk diserahkan kepada } \\
\text { masyarakat }\end{array}$ & $\mathrm{Rp}$ & - \\
\hline 6 & sub bidang kesehatan & $\mathrm{Rp}$ & $11.120 .000,00$ \\
\hline 7 & penyelenggaraan pos kesehatan desa/ polindes & $\mathrm{Rp}$ & $1.120 .000,00$ \\
\hline 8 & belanja barang dan jasa & $\mathrm{Rp}$ & $1.120 .000,00$ \\
\hline 9 & belanja barang perlengkapan & $\mathrm{Rp}$ & $1.120 .000,00$ \\
\hline 10 & belanja pakaian dinas/seragam/atribut & $\mathrm{Rp}$ & $1.120 .000,00$ \\
\hline 11 & penyelenggaraan desa siaga kesehatan & $\mathrm{Rp}$ & $10.000 .000,00$ \\
\hline 12 & belanja barang dan jasa & $\mathrm{Rp}$ & $1.000 .000,00$ \\
\hline 13 & belanja barang perlengkapan & $\mathrm{Rp}$ & $7.028 .500,00$ \\
\hline 14 & belanja alat tulis kantor dan benda pos & $\mathrm{Rp}$ & $600.000,00$ \\
\hline 15 & belanja barang cetak dan penggadaan & $\mathrm{Rp}$ & $70.000,00$ \\
\hline 16 & belanja barang konsumsi & $\mathrm{Rp}$ & $1.358 .500,00$ \\
\hline 17 & belanja bahan obat-obatan & $\mathrm{Rp}$ & $5.000 .000,00$ \\
\hline 18 & belanja jasa honorarium & $\mathrm{Rp}$ & $400.000,00$ \\
\hline 19 & belanja jasa honorarium tenaga ahli/profesi/konsultan & $\mathrm{Rp}$ & $400.000,00$ \\
\hline 20 & belanja perjalanan dinas & $\mathrm{Rp}$ & $2.571 .500,00$ \\
\hline 21 & belanja bantuan transportasi & $\mathrm{Rp}$ & $2.571 .500,00$ \\
\hline 22 & sub bidang pekerjaan umum dan penaraan ruang & $\mathrm{Rp}$ & - \\
\hline 23 & pemeliharaan alan dan lingkungan pemukiman/gang & $\mathrm{Rp}$ & - \\
\hline 24 & belanja barang dan jasa & $\mathrm{Rp}$ & - \\
\hline 25 & belanja barang perlengkapan & $\mathrm{Rp}$ & - \\
\hline 26 & belanja alat tulis kantor dan benda pos & $\mathrm{Rp}$ & - \\
\hline 27 & belanja bahan bakar minyak/gas/isi ulang & $\mathrm{Rp}$ & - \\
\hline 28 & belanja barang cetak dan penggadaan & $\mathrm{Rp}$ & - \\
\hline 29 & belanja barang konsumsi & $\mathrm{Rp}$ & - \\
\hline 30 & belanja jasa honorarium & $\mathrm{Rp}$ & - \\
\hline 31 & belanja jasa honorarium tim pelaksanaan kegiatan & $\mathrm{Rp}$ & - \\
\hline 32 & belanja jasa honorarium tenaga ahli/profesi/konsultan & $\mathrm{Rp}$ & - \\
\hline 33 & belanja jasa sewa & $\mathrm{Rp}$ & - \\
\hline 34 & belanja jasa sewa peralatan/perlengkapan & $\mathrm{Rp}$ & - \\
\hline 35 & belanja bahan dan jasa yang diserahkan kepada masyarakat & $\mathrm{Rp}$ & - \\
\hline 36 & $\begin{array}{l}\text { belanja bahan perlengkapan untuk diserahkan kepada } \\
\text { masyarakat }\end{array}$ & $\mathrm{Rp}$ & - \\
\hline 37 & sub bidang perhubungan, komunikasi dan informatika & $\mathrm{Rp}$ & $7.062 .500,00$ \\
\hline 38 & penyelenggaraan inforrmasi publik desa & $\mathrm{Rp}$ & $7.062 .500,00$ \\
\hline 39 & belanja modal & $\mathrm{Rp}$ & $7.062 .500,00$ \\
\hline 40 & belanja modal penggadaan peralatan, mesin dan alat berat & $\mathrm{Rp}$ & $7.062 .500,00$ \\
\hline 41 & belanja modal peralatan rambu-rambu/patok tanah & $\mathrm{Rp}$ & $7.062 .500,00$ \\
\hline
\end{tabular}

Sumber Data: Laporan Realisasi Anggaran Alokasi Dana Desa Tahun Anggaran 2019.

Pemerintah desa memperkirakan anggaran dibidang pelaksanaan pembangunan desa ini adalah sebesar Rp. 76.682.500,00 sedangkan yang terealisasi adalah sebesar Rp. 18.182.500,00. Bagian bidang pelaksanaan pembangunan desa terdapat beberapa sub bidang, seperti: sub bidang 
pendidikan, sub bidang kesehatan, sub bidang pekerjaan umum dan penataan ruang, sub bidang perhubungan, komunikasi dan informatika. Setiap bidang sudah dirincikan berapa nominal yang akan dikeluarkan untuk membuat sebuah kegiatan/pembangunan. Sub bidang pendidikan anggarannya sebesar Rp. 20.000.000,00 realisasinya sebesar Rp. 0,00, anggaran sub bidang kesehatan: Rp. 13.620.000,00 realisasinya: Rp. $11.120 .000,00$, anggaran sub bidang pekerjaan umum dan penataan ruang: Rp. 36.000.000,00 realisasinya: Rp. 0,00, anggaran sub bidang perhubungan, komunikasi dan informatika: Rp. 7.062.500,00 realisasinya: Rp. 7.062.500,00. Anggaran tersebut tidak terealisasi dengan baik, dikarenakan terdapat beberapa kegiatan yang tidak terlaksana, seperti: penyelenggaraan PAUD/ TK/ TPA/ KTA/ TPQ/ Madrasah, pemeliharaan lingkungan pemukiman/gang.

c. Bidang Pembinaan Kemasyarakatan

Realisasi penggunaan Alokasi Dana Desa Desa Bantan Tengah tahun anggaran 2019 pada bidang pembinaan kemasyarakatan dapat dilihat pada tabel dibawah ini:

Tabel 8 realisasi penggunaan ADD Desa Bantan Tengah Tahun anggaran 2019 Bidang pelaksanaan pembangunan desa

\begin{tabular}{|c|c|c|}
\hline No & Uraian & Realisasi \\
\hline & bidang Pembinaan Masyarakat & $\mathrm{Rp} \quad 448.611 .500,00$ \\
\hline 1 & sub bidang kebudayaan dan keagamaan & Rp $\quad 398.731 .100,00$ \\
\hline 2 & pengiriman kontingen group kesenian \& kebudayaan & $91.000 .000,00$ \\
\hline 3 & belanja barang dan jasa & Rp $\quad 91.000 .000,00$ \\
\hline 4 & belanja barang perlengkapan & $40.840 .000,00$ \\
\hline 5 & belanja alat tulis kantor dan benda pos & $33.255 .000,00$ \\
\hline 6 & belanja barang konsumsi & $11.230 .000,00$ \\
\hline 7 & belanja bendera/umbul-umbul/spanduk & $1.200 .000,00$ \\
\hline 8 & belanja pakaian dinas/seragam/atribut & $11.085 .000,00$ \\
\hline 9 & belanja barang perlengkapan & $14.000 .000,00$ \\
\hline 10 & belanja perjalanan dinas & $50.160 .000,00$ \\
\hline 11 & belanja bantuan transportasi & $50.160 .000,00$ \\
\hline 12 & penyelenggaraann festival kesenian, adat/kebudayaan & Rp $\quad 234.834 .500,00$ \\
\hline 13 & belanja barang dan jasa & Rp $234.834 .500,00$ \\
\hline 14 & belanja barang perlengkapan & $\begin{array}{ll}\mathrm{Rp} & 121.189 .500,00\end{array}$ \\
\hline 15 & belanja alat tulis kantor dan benda pos & $2.523 .000,00$ \\
\hline 16 & belanja barang cetak dan penggadaan & $6.451 .000,00$ \\
\hline 17 & belanja barang konsumsi & $99.744 .500,00$ \\
\hline 18 & belanja bendera/umbul-umbul/spanduk & $1.950 .000,00$ \\
\hline 19 & belanja pakaian dinas/seragam/atribut & $50.000 .000,00$ \\
\hline 20 & belanja barang perlengkapan & $50.291 .000,00$ \\
\hline 21 & belanja jasa honorarium & $13.350 .000,00$ \\
\hline 22 & belanja jasa honorarium tim pelaksna kegiatan & $1.200 .000,00$ \\
\hline 23 & belanja jasa honorarium tenaga ahli/profesi/konsultan & $12.150 .000,00$ \\
\hline 24 & belanja perjalanan dinas & $10.450 .000,00$ \\
\hline 25 & belanja bantuan transportasi & $10.450 .000,00$ \\
\hline
\end{tabular}




\begin{tabular}{|c|c|c|c|}
\hline 26 & belanja jasa sewa & $\mathrm{Rp}$ & $15.875 .000,00$ \\
\hline 27 & belanja jasa sewa peralatan/perlengkapan & $\mathrm{Rp}$ & $15.875 .000,00$ \\
\hline 28 & belanja barang dan jasa yang diserahkan kepada masyarakat & $\mathrm{Rp}$ & $73.970 .000,00$ \\
\hline 29 & belanja barang dan jasa yang diserahkan kepada masyarakat & $\mathrm{Rp}$ & $73.970 .000,00$ \\
\hline 30 & pemeliharaan sarana prasarana kebudayaan, rumah adat & $\mathrm{Rp}$ & - \\
\hline 31 & belanja barang dan jasa & $\mathrm{Rp}$ & - \\
\hline 32 & belanja barang dan jasa yang diserahkan kepada masyarakat & $\mathrm{Rp}$ & - \\
\hline 33 & belanja barang dan jasa yang diserahkan kepada masyarakat & $\mathrm{Rp}$ & - \\
\hline 34 & pembangunan/rehabilitasi sarana prasarana kebudayaan & $\mathrm{Rp}$ & $72.896 .600,00$ \\
\hline 35 & belanja barang dan jasa & $\mathrm{Rp}$ & $72.896 .600,00$ \\
\hline 36 & belanja barang dan jasa untuk diserahkan kepada masyarakat & $\mathrm{Rp}$ & $72.896 .600,00$ \\
\hline 37 & belanja barang untuk diserahkan kepada masyarakat & $\mathrm{Rp}$ & $72.896 .600,00$ \\
\hline 38 & sub bidang kepemudaan dan olahraga & $\mathrm{Rp}$ & - \\
\hline 39 & pembinaan karangtaruna/klub kepemudaan/olahraga & $\mathrm{Rp}$ & - \\
\hline 40 & belanja barang dan jasa & Rp & - \\
\hline 41 & belanja barang perlengkapan & $\mathrm{Rp}$ & - \\
\hline 42 & belanja alat tulis kantor dan benda pos & $\mathrm{Rp}$ & - \\
\hline 43 & belanja barang cetak dan penggadaan & $\mathrm{Rp}$ & - \\
\hline 44 & belanja barang konsumsi & $\mathrm{Rp}$ & - \\
\hline 45 & belanja perjalanan dinas & $\mathrm{Rp}$ & - \\
\hline 46 & belanja bantuan transportasi & $\mathrm{Rp}$ & - \\
\hline 47 & sub bagian kelembagaan masyarakat & $\mathrm{Rp}$ & $49.880 .400,00$ \\
\hline 48 & pembinaan lembaga adat & $\mathrm{Rp}$ & $10.000 .000,00$ \\
\hline 49 & belanja barang dan jasa & $\mathrm{Rp}$ & $10.000 .000,00$ \\
\hline 50 & belanja barang perlengkapan & $\mathrm{Rp}$ & $6.205 .000,00$ \\
\hline 51 & belanja alat tulis kantor dan benda pos & $\mathrm{Rp}$ & $1.205 .000,00$ \\
\hline 52 & belanja barang konsumsi & $\mathrm{Rp}$ & $5.000 .000,00$ \\
\hline 53 & belanja perjalanan dinas & $\mathrm{Rp}$ & $3.795 .000,00$ \\
\hline 54 & belanja bantuan transportasi & $\mathrm{Rp}$ & $3.795 .000,00$ \\
\hline 55 & pembinaan LKMD/LPM/LPMD & $\mathrm{Rp}$ & $14.360 .000,00$ \\
\hline 56 & belanja barang dan jasa & $\mathrm{Rp}$ & $14.360 .000,00$ \\
\hline 57 & belanja barang perlengkapan & $\mathrm{Rp}$ & $1.310 .000,00$ \\
\hline 58 & belanja alat tulis kantor dan benda pos & $\mathrm{Rp}$ & $460.000,00$ \\
\hline 59 & belanja barang konsumsi & $\mathrm{Rp}$ & $850.000,00$ \\
\hline 60 & belanja perjalanan dinas & $\mathrm{Rp}$ & $13.050 .000,00$ \\
\hline 61 & belanja bantuan transportasi & $\mathrm{Rp}$ & $13.050 .000,00$ \\
\hline 62 & pembinaan PKK & $\mathrm{Rp}$ & $6.118 .400,00$ \\
\hline 63 & belanja barang dan jasa & $\mathrm{Rp}$ & $6.118 .400,00$ \\
\hline 64 & belanja barang perlengkapan & $\mathrm{Rp}$ & $2.618 .400,00$ \\
\hline 65 & belanja alat tulis kantor dan benda pos & $\mathrm{Rp}$ & $1.670 .000,00$ \\
\hline 66 & belanja barang cetak dan penggadaan & $\mathrm{Rp}$ & $984.400,00$ \\
\hline 67 & belanja perjalanan dinas & $\mathrm{Rp}$ & $3.500 .000,00$ \\
\hline 68 & belanja bantuan transportasi & $\mathrm{Rp}$ & $3.500 .000,00$ \\
\hline 69 & pelatihan pembinaan lembaga kemasyarakatan & $\mathrm{Rp}$ & $5.000 .000,00$ \\
\hline
\end{tabular}




\begin{tabular}{|c|c|c|}
\hline 70 & belanja barang dan jasa & $5.000 .000,00$ \\
\hline 71 & belanja barang perlengkapan & $500.000,00$ \\
\hline 72 & belanja alat tulis kantor dan benda pos & $42.000,00$ \\
\hline 73 & belanja barang konsumsi & $458.000,00$ \\
\hline 74 & belanja jasa honorarium & $1.500 .000,00$ \\
\hline 75 & belanja jasa honorarium tenaga ahli/profesi/konsultan & $1.500 .000,00$ \\
\hline 76 & belanja perjalanan dinas & $3.000 .000,00$ \\
\hline 77 & belanja bantuan transportasi & $3.000 .000,00$ \\
\hline 78 & pembinaan LPTQ & $4.402 .000,00$ \\
\hline 79 & belanja barang dan jasa & $4.402 .000,00$ \\
\hline 80 & belanja barang perlengkapan & $4.402 .000,00$ \\
\hline 81 & belanja alat tulis kantor dan benda pos & $1.250 .000,00$ \\
\hline 82 & belanja barang cetak dan penggadaan & $350.000,00$ \\
\hline 83 & belanja barang konsumsi & $2.502 .000,00$ \\
\hline 84 & belanja bendera/umbul-umbul/spanduk & $300.000,00$ \\
\hline 85 & pembinaan MPB & $\mathrm{Rp} \quad 10.000 .000,00$ \\
\hline 86 & belanja barang dan jasa & $10.000 .000,00$ \\
\hline 87 & belanja barang perlengkapan & $5.000 .000,00$ \\
\hline 88 & belanja bahan bakar minyak/gas/isi ulang tabung & $1.600 .000,00$ \\
\hline 89 & belanja barang konsumsi & $2.500 .000,00$ \\
\hline No & Uraian & Realisasi \\
\hline 90 & belanja bendera/umbul-umbul/spanduk & $900.000,00$ \\
\hline 91 & belanja perjalanan dinas & $5.000 .000,00$ \\
\hline 92 & belanja bantuan transportasi & $5.000 .000,00$ \\
\hline
\end{tabular}

Sumber Data: Laporan Realisasi Anggaran Alokasi Dana Desa Tahun Anggaran 2019.

Pemerintah desa memperkirakan anggaran dibidang pembinaan kemasyarakatan ini adalah sebesar Rp. 461.435.500,00 sedangkan yang terealisasi adalah sebesar Rp. 448.611.500,00. Bagian bidang pelaksanaan pembangunan desa terdapat beberapa sub bidang, seperti: sub bidang kebudayaan dan keagamaan, sub bidang kepemudaan dan olahraga, sub bidang kelembagaan masyarakat. Setiap sub bidang sudah dirincikan berapa nominal yang akan dikeluarkan untuk membuat sebuah kegiatan/pembangunan. Sub bidang kebudayaan dan keagamaan anggarannya sebesar Rp. 406.295.100,00 realisasinya sebesar Rp. 398.731.100,00, anggaran sub bidang kepemudaan dan olahraga: Rp. 5.260.000,00 realisasinya: Rp. 0,00, anggaran sub bidang kelembagaan masyarakat: Rp. 49.880.400,00 realisasinya: Rp. 49.880.400,00. Anggaran tersebut tidak terealisasi dengan baik, dikarenakan terdapat beberapa kegiatan yang tidak terlaksana, seperti: pemeliharaan sarana prasarana kebudayaan dan rumah adat, pembinaan karang taruna/ klub kepemudaan / olahraga.

d. Bidang Pemberdayaan Masyarakat.

Realisasi penggunaan Alokasi Dana Desa Desa Bantan Tengah tahun anggaran 2019 pada bidang pemberdayaan kemasyarakatan dapat dilihat pada tabel dibawah ini: 
Tabel 9 realisasi penggunaan ADD Desa Bantan Tengah Tahun anggaran 2019 Bidang pelaksanaan pembangunan desa

\begin{tabular}{|l|l|ll|}
\hline No & \multicolumn{1}{|c|}{ Uraian } & \multicolumn{2}{c|}{ Realisasi } \\
\hline & Bidang Pemberdayaan Masyarakat & $\mathrm{Rp}$ & $4.650 .000,00$ \\
\hline 1 & sub bidang pebingkatan kapasitas aparatur desa & $\mathrm{Rp}$ & $4.650 .000,00$ \\
\hline 2 & peningkatan kapasitas kepala desa & $\mathrm{Rp}$ & $4.650 .000,00$ \\
\hline 3 & belanja barang dan jasa & $\mathrm{Rp}$ & $4.650 .000,00$ \\
\hline 4 & belanja perjalanan dinas & $\mathrm{Rp}$ & $4.650 .000,00$ \\
\hline 5 & belanja khusus pelatihan & $\mathrm{Rp}$ & $4.650 .000,00$ \\
\hline
\end{tabular}

Sumber Data: laporan realisasi anggaran alokasi dana desa tahun anggaran 2019.

Pemerintah desa memperkirakan anggaran dibidang pemberdayaan masyarakatan ini adalah sebesar Rp. 4.650.100,00 terealisasinya adalah sebesar Rp. 4.650.100,00. Dibidang pemberdayaan masyarakat terdapat sub bidang peningkatan kapasitas aparatur desa, kegiatan yang telah dilaksanakan adalah peningkatan kapasitas kepala desa.

e. Bidang Penanggulangan Bencana, Darurat.

Realisasi penggunaan Alokasi Dana Desa Desa Bantan Tengah tahun anggaran 2019 pada bidang pemberdayaan kemasyarakatan dapat dilihat pada tabel dibawah ini:

Tabel 10 realisasi penggunaan ADD Desa Bantan Tengah Tahun anggaran 2019 Bidang pelaksanaan pembangunan desa

\begin{tabular}{|l|l|ll|}
\hline No & Uraian & Realisasi \\
\hline & Bidang penanggulangan Bencana Darurat & Rp \\
\hline 1 & sub bidang penanggulangan bencana & Rp \\
\hline
\end{tabular}

Sumber Data: laporan realisasi anggaran alokasi dana desa tahun anggaran 2019.

Pemerintah desa memperkirakan anggaran dibidang pemberdayaan masyarakat ini adalah sebesar Rp. 4420.504,00 sedangkan yang terealisasi adalah sebesar Rp. 0,00 hal ini dikarenakan dibidang pemberdayaan masyarakat ini memiliki kegiatan yang tidak terlaksanakan yaitu: kegiatan penanggulangan bencana

Dapat dilihat dari tabel-tabel diatas yang membahas tentang realisasi penggunaan Alokasi Dana Desa Bantan Tengah Tahun anggaran 2019 belum terlaksana dengan baik, karena masih terdapat beberapa program kegiatan yang belum terlaksana/terealisasi yaitu: pembangunan/rehabilitasi/peningkatan/sarana prasarana, pengembangan sistem informasi desa, penyelenggaraan PAUD/TK/TPA/TPQ/Madrasah, pemeliharaan jalan lingkungan pemukiman/gang, pemeliharaan sarana prasarana kebudayaan, rumah adat, penanggulangan bencanaa. Hasil dari evaluasi memperlihatkan bahwa penggunaan alokasi dana desa tahun anggaran 2019 di desa bantan tengah lebih banyak digunakan untuk penyelenggaraan pemerintah desa dan pembinaan kemsyarakatan. 


\subsection{Penerapan/pelaksanaan Pengelolaan Alokasi Dana Desa Menurut Permendagri No. 114 Tahun 2014 dan No. 20 Tahun 2018.}

Penerpan dan pelaksanaan merupakan tindakan-tindakan yang dilaksnakan oleh invidu dan kelompok pemerintah maupun swasta. Yang diarahkan pada pencapaian suatu tujuan dan tepat sasaran.

Berikut merupakan tabel perbandingan penerapan/pelaksanaan alokasi dana desa tahun anggaran 2019 desa bantan tengah dengan pemendagri No 114 Tahun 2014 dan 20 Tahun 2018:

\section{Tabel 11 Penerapan/Pelaksanaan pengelolaan Alokasi Dana Desa tahun 2019 Menurut} Permendagri No. 114 Tahun 2014 \& 20 Tahun 2018

\begin{tabular}{|c|c|c|}
\hline $\begin{array}{l}\mathbf{N} \\
0\end{array}$ & $\begin{array}{l}\text { Permendagri No. } 114 \text { Tahun } 2014 \& 20 \text { Tahun } \\
2018\end{array}$ & $\begin{array}{l}\text { Pelaksanaan dan Penerapan pengelolaan } \\
\text { Alokasi Dana Desa Tahun Anggaran } 2019\end{array}$ \\
\hline \multicolumn{3}{|c|}{ Bidang Penyelenggaraan Pemerintah Desa } \\
\hline 1. & Penetapan dan penegasan batas desa. & - \\
\hline 2. & Pendataan desa & $\begin{array}{l}\text { Pengelolaan administrasi kependudukan, } \\
\text { pencatatan sipil. }\end{array}$ \\
\hline 3. & Penyusunan tata ruang desa & \\
\hline 4. & Penyelenggaraan Musyawarah desa. & $\begin{array}{l}\text { Penyelenggaraan musyawarah } \\
\text { perencanaan desa }\end{array}$ \\
\hline 5. & Pengelolaan informasi desa & - \\
\hline 6. & $\begin{array}{l}\text { Penyelenggaraan evaluasi tingkat perkembangan } \\
\text { pemerintahan desa }\end{array}$ & - \\
\hline 7. & Penyelenggaraan kerja sama antar desa & - \\
\hline 8. & Pembangunan sarana dan prasarana kantor desa. & $\begin{array}{l}\text { Penyediaan sarana prasarana pemerintah } \\
\text { desa }\end{array}$ \\
\hline 9. & Kegiatan lainnya sesuai kondisi desa. & $\begin{array}{l}\text { Penyelenggaraan belanja siltap, tunjangan } \\
\text { dan operasional perkantoran operasional } \\
\text { BPD, peningkatan kapasitas aparatur } \\
\text { pemerintah desa dan BPD }\end{array}$ \\
\hline \multicolumn{3}{|c|}{ Bidang Pelaksanaan Pembangunan Desa } \\
\hline 1. & $\begin{array}{l}\text { Pembangunan, pemanfaatan, pemeliharaan, } \\
\text { infrastruktur dan lingkungan desa } \\
\text { seperti:Tambatan perahu, jalan permukiman, jalan } \\
\text { desa antar permukiman ke wilayah pertanian, } \\
\text { pembangkit listrik dan mikrohidra, lingkungan } \\
\text { permukiman masyarakat desa }\end{array}$ & - \\
\hline 2. & $\begin{array}{l}\text { Pembangunan,pemanfaatan dan pemeliharaan } \\
\text { sarana dan prasarana kesehatan antara lain: air } \\
\text { bersih berskala desa, sanitasi lingkungan, } \\
\text { pelayanan kesehatan, sarana dan prasarana } \\
\text { kesehatan lainnya.. }\end{array}$ & $\begin{array}{l}\text { Penguatan dan peningkatan, ketertiban } \\
\text { umum dan perlindungan }\end{array}$ \\
\hline 3. & $\begin{array}{l}\text { Pembangunan, pemanfaatan, pemeliharaan } \\
\text { sarana dan prasarana pendidikan dan } \\
\text { kebudayaan antara lain: Taman bacaan } \\
\text { masyarakat, PAUD, balai pelatihan/kegiatan } \\
\text { belajar masyarakat, pengembangan dan } \\
\text { pembinaan sanggar seni, sarana dan prasarana } \\
\text { pendidikan dan pelatihan lainnya sesuai kondoisi } \\
\text { desa }\end{array}$ & - \\
\hline 4. & $\begin{array}{l}\text { Pengembangan usaha ekonomi produktif serta } \\
\text { pembangunan, pemanfaatan, pemeliharaan } \\
\text { sarana dan prasarana ekonomi antara lain: pasar } \\
\text { desa, pembentukan dan pembangunan pasar } \\
\text { desa,penguatan permodalan bumdesa, sarana } \\
\text { dan prasarana sesuai kondisi desa dan lain-lain. }\end{array}$ & - \\
\hline
\end{tabular}




\begin{tabular}{|c|c|c|}
\hline $\begin{array}{l}\mathbf{N} \\
\mathbf{0}\end{array}$ & $\begin{array}{l}\text { Permendagri No. } 114 \text { Tahun } 2014 \text { \& } 20 \text { Tahun } \\
2018\end{array}$ & $\begin{array}{l}\text { Pelaksanaan dan Penerapan pengelolaan } \\
\text { Alokasi Dana Desa Tahun Anggaran } 2019\end{array}$ \\
\hline 5. & $\begin{array}{l}\text { Pelestarian lingkungan hidup antara lain: } \\
\text { penghijauan, pembuatan terasering, } \\
\text { pemeliharaan hutan bakau, perlindungan mata } \\
\text { air, pemebersihan daerah aliran sungai, } \\
\text { perlindungan terumbu karang, dan kegiatan desa } \\
\text { lainnya }\end{array}$ & $\begin{array}{lll}\begin{array}{l}\text { Penyelenggaraan } \\
\text { desa(poster, baliho) }\end{array} & \text { informasi } & \text { publik } \\
& & \end{array}$ \\
\hline \multicolumn{3}{|c|}{ Bidang Pembinaan Masyarakat } \\
\hline 1. & Pembinaan lembaga kemasyarakatan. & $\begin{array}{l}\text { Pembinaan LKMD/LPM/LPMD, } \\
\text { karangtaruna, kepemudaan/olahraga, PKK, } \\
\text { MPB. }\end{array}$ \\
\hline 2. & Penyelenggaraan ketentraman dan ketertiban. & - \\
\hline 3. & Pembinaan kerukunan umat beragama. & - \\
\hline 4. & Pengadaan sarana dan prasarana olahraga. & - \\
\hline 5. & Pembinaan lembaga adat & Pembinaan Lembaga Adat \\
\hline 6. & $\begin{array}{l}\text { Pembinaan kesenian dan sosial budaya } \\
\text { masyarakat. }\end{array}$ & $\begin{array}{ll}\text { 1. } & \text { Pengiriman kontingen grup } \\
\text { kesenian dan kebudayaan } \\
\text { 2. } \\
\text { Penyelenggaraan festivak, } \\
\text { adat/kebudayaan }\end{array}$ \\
\hline 7. & Kegiatan lain sesuai kondisi desa. & - \\
\hline \multicolumn{3}{|c|}{ Pemberdayaan Masyarakat Desa } \\
\hline 1. & $\begin{array}{l}\text { Pelatihan usaha ekonomi, pertanian dan } \\
\text { perdagangan }\end{array}$ & - \\
\hline 2. & Pelatihan teknologi tepat guna & - \\
\hline 3. & $\begin{array}{l}\text { Pendidikan, pelatihan, penyuluhan bagi kepala } \\
\text { desa, perangkat desa dan BPD. }\end{array}$ & Peningkatan kapasitas kepala desa \\
\hline 4. & Peningkatan kapasitas masyarakat. & - \\
\hline
\end{tabular}

\section{Sumber Data: Data Olahan 2020.}

Berdasarkan tabel 5.10 dapat dilihat perbandingan antara ketentuan permendagri No 114 tahun 2014 dan No 20 tahun 2018 pada penerapan/pelaksanaan pengelolaan penggunaan alokasi dana desa tahun anggaran 2019 desa bantan tengah. Sesuai dengan hasil penelitan, penerapan/pelaksanaan pengelolaan penggunaan dana desa belum sesuai dengan pemendagri No 114 tahun 2014 pasal 17 tentang klasifikasi belanja desa dan No 20 tahun 2018 pasal 6 tentang penyusunan RPJM Desa yang memuat visi dan misi kepala desa, karena masih banyak rancangan arah kebijakan yang belum terlaksana, seperti:

1. Penetapan dan penegasan batas desa.

2. Penyusunan tata ruang desa

3. Pengelolaan informasi desa

4. Penyelenggaraan evaluasi tingkat perkembangan pemerintahan desa.

5. Penyelenggaraan kerja sama antar desa

6. Pembangunan, pemanfaatan, pemeliharaan, infrastruktur dan lingkungan desa seperti: Tambatan perahu, jalan permukiman, jalan desa antar permukiman ke wilayah pertanian, pembangkit listrik dan mikrohidra, lingkungan permukiman masyarakat desa

7. Pengembangan usaha ekonomi produktif serta pembangunan, pemanfaatan, pemeliharaan sarana dan prasarana ekonomi antara lain: pasar desa, pembentukan dan pembangunan pasar desa,penguatan permodalan bumdesa, sarana dan prasarana sesuai kondisi desa dan lain-lain.

8. Penyelenggaraan ketentraman dan ketertiban.

9. Pembinaan kerukunan umat beragama.

10. Pengadaan sarana dan prasarana olahraga. 
11. Kegiatan lain sesuai kondisi desa.

12. Pelatihan usaha ekonomi, pertanian dan perdagangan

13. Pelatihan teknologi tepat guna

14. Peningkatan kapasitas masyarakat.

\section{Kendala-Kendala yang dihadapi oleh Pemerintah Desa atas Pelaksanaan Penggunaan Dana Desa Dan Alokasi Dana Desa dibidang Pembangunan/Rehabilitasi/Peningkatan Sarana/Prasarana}

Dalam pelaksanaan program atau kegiatan yang berasal dari Dana Desa dan alokasi dana desa terdapat beberapa kendala yang dihadapi oleh pemerintah desa, sehingga proses pelaksanaan pennggunaan Dana Desa dan alokasi dana desa menjadi terhambat atau belum maksimal. Berikut uraian dari kendala-kendala yang dihadapi oleh pemerintah desa yang dirangkum berdasarkan penjelasan dari informan.

1. Kondisi yang tidak terduga

Kesejahteraan masyarakat dan pembangunan yang merata menjadi hal yang diimpikan setiap orang. Dalam pembangunan juga ada hal yang perlu diperhatikan yakni kerjasama antara pemerintah desa dan masyarakat. Berdasarkan penjelasan dari informan terdapat kendala yang tidak terduga yaitu kondisi cuaca, dimana pembangunan yang akan dilaksanakan tersebut tidak terealasiasi dikarenakan bertepatan pada musim penghujan. Sehingga, kurang tepat waktu dalam pelaksanaannya.

2. Dukungan Masyarakat

Tidak hanya pemerintah desa yang akan berperan didalam pengelolaan maupun pelaksanaan program/kegiatan yang menggunakan dana desa dan alokasi dana desa, akan tetapi masyarakat pun ikut berperan penting terutama dalam musyawarah dalam memberikan pendapat untuk penggunaan dana. Akan tetapi berdasarkan kutipan informan yang menyatakan masyarakat desa bantan tengah belum sepenuhnya memberikan dukungan terhadap penggunaan dana desa dan alokasi dana desa. Dikarenakan masyarakat belum dapat memahami dengan baik sehingga pendapat-pendapat yang diberikan saat musyawarah sulit untuk direalisasikan.

3. Kerjasama antar pihak ketiga

Kerjasama merupakan hal yang terpenting didalam pelaksanaan kegiatan baik dari sumber daya perangkat desa itu sendiri maupun dari pihak lain. Berdasarkan uraian informan mengenai kerjasama dengan pihak ketiga ini sangat kurang efektif, karena pertanggungjawaban bahan material yang akan digunakan untuk pembangunan tidak terstruktur dengan baik sehingga tidak tersedianya stock bahan material saat ingin melakukan pembangunan dengan alasan bahan material tidak tersedia di toko-toko wilayah desa tersebut.

4. Pencairan dana desa

Pencairan dana desa yang tidak dilakukan sekaligus melainkan secara bertahap oleh pemerintah menjadi salah satu kendala dalam pelaksanaan dan pengelolaan dana. Berdasarkan penjelasan dari informan proses pencairan yang dilakukan secara pertahap menimbulkan kekosongan dana di RKD pada awal tahun. 


\section{Upaya yang dilakukan pemerintah desa bantan tengah dalam penggunaan dana desa dan alokasi dana desa dibidang pembangunan/rehabilitai/peningkatan sarana/prasarana agar terealisasi dengan baik}

Menurut kaur keuangan yaitu bapak Eri menyatakan bahwa upaya yang dilakukan pemerintah desa tentang pembangunan/rehabilitasi/peningkatan sarana/prasarana ditahap berikutnya agar terealisasi dengan baik adalah dengan upaya sebagai berikut:

1. Menyeleksi kerja sama antar pihak ketiga

dengan memyeleksi kerja sama antar pihak ketiga pemerintah desa akan dapat menilai bagaimana pekerjaan yang akan dilakukan pekerja saat melaksanakan pembangunan.

2. menampung dan memilih aspirasi masyarakat dalam menyusun program yang akan direalisasikan oleh pemerintah desa.

Pemerintah desa akan menampung dan memilih program yang akan direalisasikan, jika aspirasi masyarkaat tersebut tidak dapat terjalankan/terealisasi maka pemerintah desa tidak akan memasukkan program tersebut didalam RKP Desa.

3. memanfaatkan secara maksimal dana-dana yang langsung maupun tidak langsung diperuntukkan bagi pembangunan pedesaan

untuk tahap selanjutnya pemerintah desa akan memanfaatkan dana pendaan tersebut dari dana desa maupun alokasi desa secara lebih maksimal untukmewujudkan pembangunan desa yang terealisasi dengan baik.

\section{Kesimpulan}

Realisasi Realisasi pelaksanaan penggunaan sumber dana dari dana desa yang jumlahnya sebesar Rp. 1.187.551.000,00 pada tahun anggaran 2019 didesa Bantan Tengah belum dapat terealisasi/terlaksana dengan baik karena disetiap bidang yang tercantum di laporan realisasi anggaran tahun 2019 terdapat beberapa kegiatan tidak dilaksanakan, seperti: pengelolaan perpustakaan milik desa, pembangunan/rehabilitasi/peningkatan prasarana jalan, pelatihan sosial/penyuluhan/ penyadaran tentang lingkungan hidup, penguatan dan peningkatan kapasitas tenaga keamanan, pemeliharaan pelabuhan perikanan sungai. Mengenai perbandingan penerapan/pelaksanaan dana desa tahun anggaran 2019 desa bantan tengah dengan pemendagri No 114 Tahun 2014 dan 20 Tahun 2018 juga belum sepenuhnya diterapkan karena masih banyak rancangan arah kebijakan yang belum terlaksana, seperti: Pembangunan, pemanfaatan, pemeliharaan, infrastruktur dan lingkungan desa seperti: tambatan perahu, jalan permukiman, jalan desa antar permukiman ke wilayah pertanian, pembangkit listrik dan mikrohidra, lingkungan permukiman masyarakat desa, Pelestarian lingkungan hidup antara lain: penghijauan, pembuatan terasering, pemeliharaan hutan bakau, perlindungan mata air, pemebersihan daerah aliran sungai, perlindungan terumbu karang, dan kegiatan desa lainnya, Pembinaan lembaga kemasyarakatan, Pembinaan kerukunan umat beragama, Penggadaan sarana dan prasarana olahraga, Pembinaan lembaga adat, Kegiatan lain sesuai kondisi desa, Pelatihan usaha ekonomi, pertanian dan perdagangan, Pelatihan teknologi tepat guna, Pendidikan, pelatihan, penyuluhan bagi kepala desa, perangkat desa dan BPD, Peningkatan kapasitas masyarakat. Dari hasil evaluasi mengenai dana 
yang bersumber dari dana desa didesa bantan tengah tahun anggaran 2019 memperlihatkan bahwa penggunaan dana desa didesa bantan tengah lebih banyak digunakan untuk pemeliharaan gedung/prasarana balai desa, penyelenggaraan pos kesehatan/polindesa milikdesa, penyelenggaraan posyandu dan penyelenggaraan festival/lomba kepemudaan dan olahraga.

Realisasi Realisasi pelaksanaan penggunaan sumber dana dari alokasi dana desa yang jumlahnya sebesar Rp. 2.191.341.155,00 pada tahun anggaran 2019 didesa bantan tengah juga belum dapat terealisasi/terlaksana dengan baik, karena setiap bidang yang tercantum di laporan realisasi anggaran tahun 2019 terdapat beberapa kegiatan ysng tidak dilaksanakan, seperti: pembangunan/rehabilitasi/peningkatan gedung/prasarana, pengembangan sistem informasi desa, penyelengagaraan PAUD/TK/TPA/TKA/TPQ/Madrasah, pemeliharaan jalan lingkungan pemukiman/gang, pemeliharaan sarana prasarana kebudayaan rumah adat, pembinaan karang taruna/klub kepemudaan/olahraga, kegiatan penanggulangan bencana. Mengenai perbandingan penerapan/pelaksanaan alokasi dana desa tahun anggaran 2019 desa bantan tengah dengan pemendagri No 114 Tahun 2014 dan 20 Tahun 2018 yang juga belum sepenuhnya diterapkan, karena masih banyak rancangan arah kebijakan yang belum terlaksana, seperti: Penetapan dan penegasan batas desa, Penyusunan tata ruang desa, Pengelolaan informasi desa, Penyelenggaraan evaluasi tingkat perkembangan pemerintahan desa, Penyelenggaraan kerja sama antar desa, Pembangunan, pemanfaatan, pemeliharaan, infrastruktur dan lingkungan desa seperti: Tambatan perahu, jalan permukiman, jalan desa antar permukiman ke wilayah pertanian, pembangkit listrik dan mikrohidra, lingkungan permukiman masyarakat desa, Pengembangan usaha ekonomi produktif serta pembangunan, pemanfaatan, pemeliharaan sarana dan prasarana ekonomi antara lain: pasar desa, pembentukan dan pembangunan pasar desa,penguatan permodalan bumdesa, sarana dan prasarana sesuai kondisi desa dan lain-lain, Penyelenggaraan ketentraman dan ketertiban, Pembinaan kerukunan umat beragama, Pengadaan sarana dan prasarana olahraga, Kegiatan lain sesuai kondisi desa, Pelatihan usaha ekonomi, pertanian dan perdagangan, Pelatihan teknologi tepat guna, Peningkatan kapasitas masyarakat Dari hasil evaluasi mengenai alokasi dana desa didesa bantan tengah tahun anggaran 2019 memperlihatkan bahwa penggunaan dana desa didesa bantan tengah lebih banyak digunakan untuk penyelenggaraan belanja siltap, tunjangan dan operasional desa dan pembinaan kemasyarakatan.

Pelaksanaan penggunaan dana desa dan alokasi dana desa tahun anggaran 2019 pada desa bantan tengah dibidang pembangunan/Rehabilitasi/Peningkatan Sarana/Prasarana belum dapat terealisasi/terlaksana dengan baik dikarenakan terdapat beberapa kendala yang dihadapi yaitu: kondisi yang tidak terduga, pengerjaan pembangunan didalam musim penghujan sehingga menjadi penghambat dalam pengerjaan pembangunan tersebut, kurangnya dukungan masyarakat desa, kerjasama antar pihak ketiga belum berjalan dengan baik, kurangnya komunkasi dan tanggungjawab oleh pihak ketiga mengakibatkan bahan material yang akan digunakan untuk pembangunan tidak terstruktur dengan baik sehingga tidak tersedianya stock bahan material saat ingin melakukan pembangunan dengan alasan bahan material tidak tersedia di toko-toko wilayah desa tersebut, pencairan dana yang dilakukan secara bertahap yang membuat kekosongan kas saat ingin melakukan pembangunan.

Sejauh ini, yang menajdi fokus utama dalam upaya yang akan dilakukan pemerintah desa Bantan Tengah untuk penggunaan Dana Desa dan Alokasi Dana Desa 
dibidang pembangunan/Rehabilitasi/Peningkatan Sarana/Prasarana diitahap berikutnya agar terealisasi dengan baik adalah: menyeleksi kerja sama antar pihak ketiga dalam memberikan tender pengerjaan pembangunan agar pihak ketiga bisa lebih bertanggungjawab atas pekerjaan yang telah diberikan, menampung dan memilih aspirasi masyarakat dalam menyusun program yang akan direalisasikan oleh pemerintah desa, dikarenakan masyarakat desa juga menjadi bagian dari kegiatan yang telah disusun oleh pemerintah desa, dengan adanya ide atau aspirasi dari masyarakat yang lebih terarah maka pemerintah desa bisa melaksanakan kewajiabannya untuk mensejahterakan masyarakat desa, memanfaatkan secara maksimal dana-dana yang langsung maupun tidak langsung diperuntukkan bagi pembangunan pedesaan, dana dana yang telah masuk kekas desa harus lebih digunakan untuk kegiatan dan pembangunan yang lebih bisa diterima dikalangan masyarakat desa bantan tengah khususnya.

\section{Saran}

Berdasarkan informasi-informasi yang penulis dapatkan pada saat pengumpulan data serta hasil analisis dari penelitian, berikut saran yang dapat penulis berikan:

Kepala desa perlu melakukan sosialisasi dan pengenalan terkait dengan kebijakan-kebijakan dalam tata cara pengelolaan dana desa dan alokasi dana desa kepada perangkat desa, sehingga perangkat desa memiliki kemampuan yang memadai dalam pelaksanaan kegiatan pengelolaan dana desa dan alokasi dana desa sesuai dengan peraturan yang berlaku.

Pemerintah desa juga perlu mengadakan sosialisasi mengenai prioritas penggunaan dana desa dan alokasi dana desa kepada masyarakat, agar masyarakat mengetahui proses penerapan/pelaksanaan penggunaan dana desa dan alokasi dana desa. Sehingga usulan-usulan program kegiatan yang diberikan oleh masyarakat menjadi lebih terarah dan dapat direalisasikan.

Masyarakat desa untuk kedepannya harus memiliki kemauan dan kerjasama yang baik dengan pemerintah desa dalam upaya meningkatkan kualitas dan menggali potensi yang ada dimasyarakat untuk menjalankan program kegiatan yang telah diusulkan agar berjalan dengan baik.

Diharapkan untuk peneliti selanjutnya, mampu mengidentifikasi programprogram yang telah dilaksanakan oleh pemerintah desa yang tidak hanya menggunakan sumber dana dari dana desa dan alokasi dana desa saja. Hal tersebut dimaksud agar penelitian selanjutnya dapat memberikan gambaran mengenai program-program yang terealisasikan menggunakan semua dana yang didapatkan oleh desa.

\section{Referensi}

Handayani, N.A. (2019). Evaluasi Kebijakan Alokasi Dana Desa Dalam Pembangunan Desa di Desa Jetiskarangpung Kecamatan Kalijambe Kabupaten Sragen. Ji@P,6(1), 2355-4223.

Pasodung, O.C, \& Tinangon, J.J. (2017). Evaluasi penggunaan dana desa tahun 2015 pada badan pemberdayaan masyarakat kampung dan transmigrasi (bpmkt) kabupaten kepulauan yapen,papua Anggaran Pendapatan Dan Belanja Desa (APBDes) Tahun 2017 (Studi Kasus di desa kategori tertinggal pada Kecamatan Kintamani, Kabupaten Bangli). Jurnal Accountability, 06,(01), 72-80. 
Peraturan Menteri Dalam Negeri No. 114 tahun 2014 Tentang Pedoman Pembangunan Desa

Peraturan Menteri Dalam Negeri No. 20 tahun 2018 Tentang Pengelolaan Keuangan Desa

Peraturan Pemerintah No. 72 Tahun 2005 Tentang Desa

Peraturan Perundang-Undangan No. 6 Tahun 2014 Tentang Dana Desa

Sugiyono, S. (2017). Metode Penelitian Kuantitatif, Kualitatif dan R\&D. Bandung :Afabeta.

Suharyono, S., \& widodo, T. (2017). Analisis Hasil Belajar Mahasiswa Dalam Mata Kuliah Komputer Akuntansi. Inovbiz: Jurnal Inovasi Bisnis, 5(1), 29-35.

suharyono, S. (2019). Pengaruh MYOB Test Clinic Terhadap Kompetensi Mahasiswa. Jurnal Analisa Akuntansi, 2(2), 54-64.

Suharyono, S. (2018). The Effect of Applyibg E-Filling Applications towards Personal Taxpayer Compliance in Reporting Annual Tax Returning (SPT) in Bengkalis State Polytechnic Indonesia. International Journal of Public Finance, 3,(1), 47-62. 